\title{
TEXTO, COMUNICACIÓN Y CULTURA EN LOS RÍOS PROFUNDOS DE JOSÉ MARÍA ARGUEDAS
}

Cuando José María Arguedas publicó en 1958 su novela Los ríos profundos era considerado ya como el más importante narrador peruano de tema indígena. Agua (1938), Yawar fiesta (1941), y Diamantes y pedernales (1954) configuraban una visión del mundo andino desde su interior, tanto porque Arguedas comunicaba la percepción cultural nativa como porque lo hacía desde su fecundo trabajo sobre las formas lingüísticas del quechua. Al mismo tiempo que una poderosa denuncia de la situación social aborigen, esos libros eran un retrato tierno y a veces idílico, pero también convulsionado y a veces violento, de la vida peruana indígena que, hasta antes de José María Arguedas, no había tenido un autor mayor que la reelaborara en el texto literario.

Pero con la aparición de Los ríos profundos José María Arguedas demostró que su importancia era otra, menos obvia: no sólo la de haber descubierto un mundo nativo sino también la de revelar una nueva literatura, que él iniciaba con esta novela, clausurando el viejo indigenismo de buena voluntad y comenzando la moderna lectura de ese mundo discordante que resultaba ser el más nuestro, el más próximo y propio. Con esta novela el universo indígena peruano ingresa a la literatura universal por medio de un texto fundamental, cuya calidad literaria fue de inmediato reconocida. Pero, sobre todo, con esta novela ese mismo universo se convierte en el lenguaje ficticio de una verdad irrefutable, aquella de la imaginación lírica y la denuncia moral, de la percepción mítica y la opción poética.

Por los años de la aprición de Los rios profundos la crítica peruana hablaba de una narrativa "urbana" y otra "rural", división topográfica que cedía el predominio a la primera, en relación simétrica a las estadísticas. Sin embargo, precisamente una novela como la de Arguedas demuestra que esa fue una distinción trivial. Lo cierto es que Los rios profundos no es únicamente novela acerca del mundo andino y provinciano, sino reformulación radical de los modelos que han configurado nuestra percepción nacional. En este sentido, es un texto literario que actúa también como un texto de cultura. Más específicamente se podría decir que el texto dramatiza un "programa de cultura" como una alternativa de ficción.

En este trabajo propongo un análisis formal de esta novela en su organización textual $y$ en su estructuración semántica de la comunicación. Creo posible demostrar que el texto genera un sistema de comunicación peculiar, y, al mismo tiempo, que este sistema dramático y desgarrado reformula el sentido del texto. Creo que sobre el debate de la comunicación se organiza peculiarmente el relato.

Parto de la crítica moderna sobre la comunicación en literatura, lo que me exime de presentar la genealogía del tema y las variantes del modelo lingüístico en la teoría. Me limito aquí a describir cómo el propio texto formaliza su sistema de comunicación y cómo confronta los modelos que distinguen a los ha- 
blantes. Por eso entiendo comunicación a base del esquema de las funciones de Jakobson y del esquema de los actantes en Greimas; todo ello desde la perspectiva semiótica de aprehender la cultura como el intercambio y el procesamiento de la información, esto es, como la disputa social por la información.

\section{EL NARRADOR PLURAL}

Los rios profundos ${ }^{1}$ ha merecido seria atención crítica en varios de sus aspectos fundamentales ${ }^{2}$. Pero resta todavía por hacer una lectura de su sistema de comunicación, que es fundamental a la misma producción del texto y que, como veremos, in forma también a la indagación por el sentido que mueve su escritura. La naturaleza del conflicto puede ser entendida en esta novela como el drama de una comunicación, en primer lugar, estratificada socialmente; y, en segundo lugar, como el drama disyuntivo de sistemas de comunicar que suponen distintas series de transmisión, procesamiento y jerarquización de la información. Por lo mismo, son modelos de percepción los que se disputan en el texto el espacio de la comunicación. O sea, se disputan el orden de los hechos, la definición de los hablantes y el lugar del sujeto. El drama de la comunicación es la forma desgarrada de la existencia social misma: son modelos culturales en conflicto los que generan este relato del papel de los hablantes. Precisamente, Los ríos profundos puede ser leído, en esta perspectiva, como un texto de cultura ${ }^{3}$ cuya semiosis, cuya producción de sentido, requiere redefinir la función de los actores de la comunicación ${ }^{4}$.

\section{Narración y lectura: voces y funciones}

El "texto social" (los conflictos étnicos y de clase) y el "texto de cultura" (los conflictos de la información) ${ }^{5}$, se fundirán en el "texto

José MARÍa ARguedas, Los rios profundos, Buenos Aires, Losada, 1958. Cito por la cuarta edición en la Biblioteca Clásica y Contemporánea de esa editorial. Las páginas se dan en el texto.

2 Véanse especialmente los trabajos de Sara Castro-Klarén, Antonio Cornejo Polar (Los universos narrativos de José María Arguedas, Buenos Aires, 1976) y William Rowe (Mito e ideología en la obra de José Maria Arguedas, Lima, 1979). Una bibliografía de W. Rowe puede consultarse en el número especial de la Revista Peruana de Cultura, 1970, núms. $13 / 14$ dedicado a Arguedas. Un estudio de la estrategia narrativa ha sido adelantado por SARA CASTRO-KLARÉN en el capítulo "Un mundo cerrado" de su libro El mundo mági. co de José María Arguedas, Lima, 1973.

3 Véase B. A. USPENSKY et al., "The semiotic study of cultures", en JANVANDER ENG y MOJMIR GR YGAR, Structure of texts and semiotic of culture, The llague, 1973.

4 Sobre semiótica de la cultura puede consultarse además École de Tartu, Travaux sur les systèmes des signes, Bruselas, 1976, y la edición de DANIEL P. LUCID, Soviet semiotics, an anthology, Baltimore, 1977.

"Sobre la noción de "texto" como práctica semiótica, véase JULIA KRISTEVA, El tex to de la novela, Barcelona, 1974, así como su trabajo "La productivité dite texte", Communication, 1968, núm. 11. Véase también JURI LOTMAN, La structure du texte artistique, Paris, 1973 y WALTER D. Mignolo, Elementos para una teoria del texto literario, 
literario" como forma dramática de la aventura informativa del sujeto. Desde la perspectiva del aprendizaje, de la socialización no menos desgarradora, el "relato" dará cuenta de la exacerbación de los conflictos; porque es la subjetividad de Ernesto, un muchacho de catorce años, la que pondrá a prueba la jerarquía y la zozobra de los sistemas. $Y$ desde el recuento de estos procesos el "discurso" prolongará el sentido del relato al exteriorizar en un texto, a su vez en conflicto con su linaje narrativo, esta compleja exploración del sujeto y su aventura constitutiva ${ }^{6}$.

De ahí que para controlar las series de información disyuntiva y en competencia, así como para re-escribir el relato oral y temporal con el recuento reordenador que fija al sentido como lenguaje inscrito, el Narrador de esta novela requiera ser uno y plural. En el espacio mayor del texto, el narrador ocupa el presente de la escritura: es el "yo" del autor, que establece y sitúa el relato con las exteriorizaciones del recuento y del balance. En un segundo espacio incluyente, es el "yo" testigo, que da paso al informe, y cuya función es ampliar lo específico cultural en las expansiones del discurso y las precisiones de la denuncia. Y, en fin, en la dimensión misma del relato es el "yo" actor, que supone al niño protagonista y su actualidad abierta al acontecimiento y su dramaticidad. Si el primer narrador responde por la escritura de un texto, su acto de emisión se cumple como la enunciación; y presupone en la lectura una organización de sus materiales como "novedad", como información que requiere ser mediada, procesada y afirmada por la autoridad protagónica del lenguaje. Si el segundo narrador responde por la diferencia de una cultura, su papel está en ilustrar esa enunciación como "verdad". Y si el tercero sostiene, en cambio, el relato como enunciado, quiere decir que su función se cumple en la "ficción". Así, este narrador plural construye una lectura sistemática implícita: como "autor" remite a una diferencia, a la certidumbre que refiere el "testigo"; ambos coinforman un "actor", cuya lectura discierne el proceso de aprendizaje (de información) que lo distingue ${ }^{7}$.

La interacción de las voces narrativas es inmediata, y hasta simultánea, ya que el texto busca integrar a los narradores en el discurso de su propio conflicto. Al mismo tiempo, los tipos de discurso (novela, informe, biografía) actúan como inclusiones; y pueden desplazarse

Barcelona, 1978. Una importante colección es la editada por CHARLES BOUAZIS, Essais de la théorie du texte, Paris, 1973

"Sobre la distinción relato/discurso, véase GÉRARD GENETTE, "Discours du récit", en su Figures III, Paris, 1972. Una ilustrativa aplicación del modelo de Genette es la que hace CHRISTINE BROOKE-ROSE en "Transgressions: An essay-say on the novel novel novel", en Contemporary literature, 19 (1978), 378-407.

7 Roland Barthes se refiere al acto comunicativo autor/lector en su estud io "Analyse textuelle de un conte de Edgard Poe", en Sémiotique narrative et textuelle, éd. C. Chabrol, Paris, 1973, pp. 29-54; trad. esp. en Lingüística y literatura, ed. R. Prada Oropeza, Xalapa, México, 1978. Véase también MICHEL CHARLES, Rhétorique de la lecture, Paris, 1977. 
de un narrador a otro. Del mismo modo, la lectura que los narradores implican (son, claro, voces de un mismo Narrador) actúa como la conciencia más amplia del texto; incluye al mismo "yo autor" quien, sabiamente, no resuelve los conflictos, sino que se moviliza hacia su máscara de "actor" (niño) para potenciarlos. En fin, la "función" es aquí el modo en que la estrategia narrativa significa narrador-lector. Ciertamente, la interacción es mayor: la "biografía", por ejemplo, supone una "vida del actor" como escritura; y el "descubrimiento" una operación del texto por la cual al revelarse como autor (adulto) el Narrador se entrega a la suerte del conflicto del actor (niño).

Insisto en esta pluralidad sistemática del Narrador de Los rios profundos porque una parte de la crítica ha difundido la idea de que Arguedas fue poco menos que un escritor "ingenuo", y esta novela una versión idílica y "roussoniana" de la'naturaleza ${ }^{8}$. La verdad es más compleja. También más interesante.

Un análisis más detallado de las operaciones textuales del Narrador demostraría que en su pluralidad radica su capacidad de controlar y discernir la información que está textualizándose, transformándose en discurso del relato. Ya en la primera página de la novela vemos el funcionamiento de esa perspectiva múltiple: El "narrador-testigo" lo es, en primer término, de la relación del lector y su texto; y, por ello, requiere al escribir el término "colonos" introducir una llamada aclaratoria: "Indios que pertenecen a las haciendas". Esta actividad de notación dejará, en la mayoría de los casos, el margen del pie de página y se introducirá en el tejido mismo del relato. Leemos enseguida: "Eran parientes, y se odiaban. Sin embargo, un extraño proyecto concibió mi padre, pensando en este hombre. Y aunque me dijo que viajábamos a Abancay, nos dirigimos al Cuzco, desde un lejanísimo pueblo. Según mi padre, íbamos de paso. Yo vine anhelante, por llegar a la gran ciudad. Y conocí al Viejo en una ocasión inolvidable" (7).

El inicio de este capítulo es, como el de otros, una suerte de introducción. El código retórico tiene como función predisponer y alertar la recepción del lector, y un estudio de este código revelaría que el texto reconoce un fino trabajo estratégico de control de su información a la vista de la recepción. Por eso, estas introducciones (como al inicio del capítulo 6) requieren el relieve de una de las tres voces narrativas y el concurso de las otras dos. En este caso, luego de la notación que introduce el "narrador-testigo", vemos que aparece el "narrador-autor" desde el recuento: su texto introductorio es a la vez una presentación del relato consumado y una definición del carácter de la acción ("Eran parientes, y se odiaban").

Los tiempos narrativos sostienen la fuente de la información desde

${ }^{8}$ Algunos de los que han comentado esta novela sugieren que de ella se deduce una visión irracionalista, es decir, una manipulación de mitos fabricados por el autor. Sin embargo, la racionalidad del mito en el tex to es evidente, como esperamos demostrarlo al final de este trabajo. 
las diferentes apariciones del Narrador, lo que es también explícito cuando se trata de precisar el contex to y su consiguiente inclusión en el relato. En el capítulo 4, luego de la introducción del "narrador-testigo" sobre los hacendados, leemos: "Abancay está cercado por las tierras de la hacienda Patibamba. Y todo el valle, de sur a norte, de una cima a la otra, pertenece a las haciendas" (44). El "narrador-testigo" introduce aquí el tiempo presente para fijar la naturaleza del es. pacio (código del lugar dual); y para propiciar la textualización siguiente del espacio en el tiempo narrativo histórico: "El parque de Patibamba estaba mejor cuidado y era más grande que la Plaza de Armas de Abancay. . . La casa tenía arquería blanca. . . En una esquina de la huerta habia una pajarera alta. . . La jaula tenía varios pisos. .." Esta enumeración revela la amplia mirada del "narrador-autor", cuyo recuento incluye al "actor", su mirada reconstruida en el tiempo plural y virtual que los liga. "Yo fui muchas veces a mirar desde la reja", sigue informándonos este recuento; y "sólo una vez escuché desde ese sitio la voz de un piano". Vemos que el "autor" discierne en el "actor" una ocurrencia; la cual, de inmediato, se actualiza: "alguien tocaba". El "actor" ocupa enseguida el tex to; y el espacio intensifica su conversión en relato: "A poca distancia de la casa-hacienda el callejón ya estaba cubierto de bagazo", donde el adverbio temporal anuncia el presente inmediato. En efecto, el relato se impone ("El sol arde sobre la miel seca", 45) en el presente que recobra ai "actor". La interacción no es, sin embargo, deductiva: es simultánea; una ocurrencia, un movimiento alterno que anuncia, por cierto, el drama del sujeto en la escritura ${ }^{9}$. Volveremos sobre esto.

\section{Paradigmas de la comunicación}

La relación polar entre Viejo/viaje (capítulo 1: "El Viejo", cap. 2: "Los viajes"), que inicia la acción de la novela, señala el origen del conflicto en un tex to que buscará rehacer el sentido mismo de la comunicación. Esta dualidad anuncia el código de la ambivalencia, que polariza hablantes, espacios, grupos, en las disyunciones del sentido ilustradas por el relato. El Viejo, en efecto, es el pariente poderoso que señorea desde el Cuzco, el centro antiguo del sentido, en la distorsión actual introducida en el mundo por el poder y su distinta jerarquización y valoración. El padre, en cambio, es el errante (el "loco", el que carece de lugar), y su dispersión es también un signo agónico de la desarticulación del sentido genuino, el que construye una percepción alternativa hoy sancionada.

9 Sobre el narrador véase la obra citada de J. KRISTEVA, El texto de la novela; PERCY LUBBOCK, The craft of fiction, New York, 1921; y WAYNE C. BOOTH, The rihetoric of fiction, Chicago, 1961. Es interesante la discusión de LUDOMIR DOLEZEL, "The typology of the narrator: Point of wiev in fiction", en To honor Roman Jakobson, La Haya, 1967, t. 1, pp. 541-552. Véase también TZVETAN TODOROv, Poétique de la prose, Paris, 1971. 
El inicio de la novela con el regreso a un Cuzco ocupado por el oponente es de por sí emblemático. Este retorno frustrado al paraíso patriarcal ("El Cuzco de mi padre. . . no podía ser ese",) es una figura que preside el conflicto con la usurpación del lugar y la substitución del sentido. El lugar y el sentido han sido desterrados, y desde este exilio el texto se producirá como una revisión radical de los modelos en disputa. El relato del aprendizaje permitirá actualizar esa disputa. En este sentido, el recomienzo del mundo en el texto supone que su exteriorización como información es puesta a prueba por las reacciones de un niño.

Como en Pedro Páramo de Juan Rulfo, en la culpabilidad del Viejo subyace un esquema mítico: la distorsión del espacio original se deduce de la distorsión del líder. El Viejo "grita con voz de condenado" y "almacena las frutas de las huertas, y las deja pudrir" (7). La oposición entre ambas figuras patriarcales (padre/tío) se reproduce en la misma configuración del lugar: sobre el muro incaico de piedra se ha levantado la pared blanca hispánica ${ }^{10}$. La casa del Viejo está "en la calle del muro inca" (8) y hasta el árbol del patio es en ella "bajo y de ramas escuálidas" (9). Allí se produce el encuentro con el pongo ("indio de hacienda que sirve gratuitamente, por turno en la casa del amo", informa a pie de página el "narrador-testigo" (9), que será paralelo del encuentro con el muro incaico. Ernesto, el "narrador-actor", no había conocido, antes de esta visita al Cuzco, ambos signos paradigmáticos de la comunicación.

Convertida oprobiosamente en urinario público, la calle del muro incaico se restituye en la comunicación; sus piedras labradas se transforman en la percepción del niño: "Toqué las piedras con mis manos; seguí la línea ondulante, imprevisible, como la de los ríos, en que se juntan los bloques de roca. En la oscura calle, en el silencio, el muro parecía vivo, sobre la palma de mis manos llameaba la juntura de las piedras que había tocado" (10).

Este acto de comunicación se inicia, así, como un ritual de reconocimiento: el niño transmuta la materia cultural (un monumento incaico) en materia original (los ríos tutelares de la infancia). De este modo, el orden natural se establece como un modelo realizado, pleno, que no sólo supone a la "naturaleza" o al "paisaje", sino a una organización del sentido que incluye al sujeto y al mundo natural como una integridad continua en un modelo de cultura, el cual, en el texto, será esencialmente un modelo de comunicación. No es casual, por ello, que Ernesto confronte a partir de este ritual los infortunios del viaje paterno con la promesa del lugar patriarcal: "Cuando mi padre hacía frente a sus enemigos. . yo meditaba en el Cuzco. Sabía que al fin llegaríamos a la gran ciudad" (11). Esa promesa se ha frustra-

10 "La pared blanca del segundo piso empezaba en línea recta sobre el muro", p.8. El estudio sobre el espacio y su estructuración en esta novela requeriría un trabajo aparte. 
do pero, en cambio, a través del ritual frente al muro se ha afirmado una vinculación verificadora del sentido entrevisto. De allí que se imponga, enseguida, un diálogo de reconocimiento (una nominación identificadora del emisor y del destinatario) en el código de la comunicación modeladora, esto es, en el quechua original:

Me acordé, entonces, de las canciones quechuas que repiten una frase patética constante: yawar mayu, río de sangre; yawar unu, agua sangrienta, puk'tik, yawar k'ochoa, lago de sangre que hierve; yawar wek'e, lágrimas de sangre. ¿Acaso no podría decirse yawar rumi, piedra de sangre, o puk'tik, yawar rumi, piedra de sangre hirviente? Era estático el muro, pero hervía por todas sus líneas y la superficie era cambiante, como la de los ríos en el verano, que tienen una cima así, hacia el centro del caudal, que es la zona temible, la más poderosa. Los indios llaman "yawar mayu" a esos ríos turbios, porque muestran con el sol un brillo en movimiento, semejante al de la sangre (...)

- iPuk'tik, yawar rumi! -exclamé frente al muro, en voz alta.

$Y$ como la calle seguía en silencio, repetí la frase varias veces (11).

Este bello pasaje es suficientemente explícito. El ritual de la comunicación reclama la enunciación de los nombres identificatorios, que son elementales; o sea, la construcción misma de un enunciado primero. Dar nombre significa aquí fundir esos elementos (agua, piedra, sangre) en la palabra reveladora de la mutua identidad. La cultura como información, y como fuente de la información, es capaz de reordenar y restituir una plenitud del sentido en el acto mismo de la comunicación. Tampoco es casual que las tres voces del Narrador se cedan aquí mutuamente la palabra.

Desde esta instancia modeladora, la percepción de Ernesto procederá a reordenar e interpretar la información en un orden diferente de los hechos. "Papá - le dije. Cada piedra habla" (12), concluye Ernesto, y trata de revisar la misma información de su padre. El muro, cree él, podría devorar a los señores avaros del Cuzco; el modelo cultural es también moral, y la disyunción del bien y del mal está planteada como una lucha por la información; esto es, como la disputa de sistemas de comunicar que significan de modo diverso. La imposición de un poder antinatural ha decidido, en el orden social, la injusticia presente que es, en primer término, un desorden, una des-naturalización. Y, sin embargo, la convicción que emerge en Ernesto impone su propio sistema de conversiones. Cuando ve la catedral, por ejemplo, leemos: "Era la más extensa de cuantas había visto. Los arcos aparecían como en el confín de una silente pampa de las regiones heladas"; y también: "Era una inmensa fachada; parecía tan ancha como la base de las montañas que se elevan desde las orillas de algunos lagos de altura" (13). O sea, otro monumento cultural es incorporado al orden de la percepción natural, desde donde se miden y valoran. También ante la apelación que percibe en la figura de la catedral ("No era imponente, recreaba"), el niño necesita responder: “Quise 
cantar junto a su única puerta. No deseaba rezar" (15). Como ios indios, quiere cantar un himno pero, advierte, sin llanto. Reveladoramente, este monumento hispánico está también hecho de piedra ("Llamamos roca viva, siempre, a la bárbara"), nos ilustra el "narrador-autor", ahora ocupando el "nosotros" de una cultura que disputa su información (15); pero está hecho de una piedra distinta, aparentemente anómala. El recorrido consiguiente de otros templos no hace sino reforzar esta disputa entre la piedras incaicas y los muros coloniales. En el palacio de Huayna Capac las piedras "no bullían, no hablaban" (16) porque "era el muro quien imponía silencio". La comunicación ha sido, así, ya sancionada.

El conflicto no es simplemente entre los objetos indígenas y los hispánicos; esta oposición depende, más bien, de la percepción cultural y del orden en que esos objetos se sitúan culturalmente. Por ejemplo, el "canto de la María Angola (la campana legendaria de la catedral cuzqueña), a pesar de ser un objeto hispánico, funciona en el orden cultural que el niño está sosteniendo. Ante su canto, leemos: "La tierra debía convertirse en oro en ese instante; yo también, no sólo los muros y la ciudad..."(16); porque "el canto se acrecentaba, atravesaba los elementos". De inmediato, este "mensaje" de la campana convoca en la memoria a otras campanas de pueblos indígenas: "Pensé que esas campanas debían de ser illas, reflejos de la «María Angola », que convertiría a los amarus en toros. Desde el centro del mundo, la voz de la campana, hundiéndose en los lagos, habría transformado a las antiguas criaturas"'(17). El pasaje es ilustrativo: anuncia el sincronismo religioso implícito en esta percepción que, por cierto, está hecha de elementos nativos y elementos hispánicos integrados en un mestizaje variable, pero cuya organización no deja de ser básicamente andina. En este caso, el canto poderoso de la campana hispánica ha convertido a los amarus (serpientes), elemento quechua, en toros, elemento hispánico. La conversión puede ser alegórica, pero la explicación sigue siendo mítica, propia del pensamiento andino ${ }^{11}$. $\mathrm{Al}$ mismo tiempo, no es menos evidente que este "canto" evoca también a "mis protectores, los alcaldes indios"'(16); y ésta es otra imagen tutelar del mundo sustantivo que ha incorporado también las campanas a su comunicación mítica. Ya vemos, pues, que no es meramente lo "indígena" y lo "hispánico" lo que está en disputa, sino dos órdenes que pueden incorporar a su percepción y modelización elementos de una y otra fuente de información. El mismo Ernesto vivirá el conflicto de definir un orden en el espacio del otro.

Otro emblema de la comunicación, la figura del pongo, que Ernes-

11 Una importante contribución al análisis del pensamiento andino es la compilación de JUAN OSSIO, Ideología mesiánica del mundo andino, Lima, 1973. Véase también NATHAN WACHTEL, La vision des vaincus, Paris, 1971, así como LUIS Millones. "Sociedad indígena e identidad nacional", en la fundamental compilación de C. Arróspide de la Flor et al, Perú: identidad nacional, Lima, 1979. 
to ha descubierto en el Cuzco, no es menos ilustrativo y decisivo en este debate. Otras veces José María Arguedas se ha detenido en esta figura extraordinaria de la orfandad indígena y de la violencia del sistema de la hacienda en la Sierra peruana ${ }^{12}$. La humillación que marca su papel de siervo es negación de su misma condición humana: "se podía percibir el esfuerzo que hacía por apenas parecer vivo, el invisible peso que oprimía su respiración" (21). Después de la exaltación identificatoria del primer paradigma, el niño intenta comunicarse con el pongo:

Le hablé en quechua. Me miró extrañado.

- ¿No sabe hablar? -le pregunté a mi padre.

- No se atreve -me dijo. A pesar de que nos acompaña a la cocina.

En ninguno de los centenares de pueblos donde había vivido con mi padre, hay pongos.

- Tayta -le dije en quechua al indio. - ¿Tú eres cuzqueño?

-Mánan -contestó. De la hacienda (17).

El emisor apela al código común del quechua pero el destinatario carece de un papel en la comunicación, que lo distinguiría como un ser específico: su papel de siervo lo excluye del habla misma, que lo aterra. Y aun cuando responde da como su origen, en verdad, su pertenencia, a un sistema económico, la hacienda, base de su papel dominado. El uso del habla le está vedado como comunicación distintiva. La estratificación social impone una distorsión del acto mismo de comunicar, estableciendo entre los hombres un ejercicio diferenciado del habla: la sanción de unos, la manipulación de otros. En Los rios profundos la complejidad de este conflicto sustentará su poderosa de. nuncia del habla usurpada.

El Viejo representa, como es claro, el sistema dominante usurpador. Después de dormir en su casa, y habiendo sido humillado por el Viejo que los alojó en la cocina, en un lugar inferior de la casa, Ernesto y su padre deben todavía enfrentar al poderoso señor, cuyo estigma (la avaricia) es otra señal de su poder distorsionado. Este enfrentamiento, reveladoramente, es resuelto por Ernesto en un acto de comunicación que él logra definir:

- ¿Cómo te llamas? -me preguntó el Viejo, volviendo a mirarme.

(...)

-Me llamo como mi abuelo, señor. -le dije.

- ¿Señor? ¿No soy tu tío?

(...)

-Es usted mi tío. Ahora ya nos vamos, señor -le contesté.

Vi que mi padre se regocijaba, aunque permanecía en actitud casi solemne (21).

12 El pongo es actor central de la bella parábola sobre el mundo al revés reordenado luego de la muerte, que Arguedas escribió sobre un cuento quechua: "El sueño del pongo", en sus Relatos completos, Buenos Aires, 1974. 
Otra vez los nombres definen la sustancia de la comunicación. En este caso no sólo se establece una diferenciación entre el sistema de parentesco (que denomina un reconocimiento mutuo) y las marcas de objetivación de los hablantes ("señor" apela a la impersonalidad del acto); sino que, sobre todo, el acto de comunicación se establece como una reiteración de su situación, que aquí podemos llamar identificatoria, y que supone poner a prueba las funciones comunicativas (precisadas por Jakobson) en la autorreferencialidad del acto mismo de comunicar. En este sentido, el pasaje es elocuente. El emisor (el Viejo) y el destinatario (el niño) van a definirse a través de esta situación identificatoria: a la pregunta por su nombre que le ha dirigido el Viejo (preguntar por el nombre es un signo de la autoridad del emisor en el acto de la comunicación), el niño responde con un subterfugio (rehusar el nombre propio es poner en cuestión el papel del destinatario: remitirse en este caso al nombre del abuelo es apelar a una autoridad patronímica superior). De inmediato, el emisor percibe que su papel ha sido cuestionado por un subdiscurso que al parentesco impone la impersonalidad de los sujetos hablantes. Alarmado, pregunta por sí mismo, reclama ser definido no como "señor" sino como "tío", como autoridad familiar y como autoridad del habla. En otro subterfugio que define aún más la identificación recusadora, el niño replica con las dos categorías: acepta la fatalidad del parentesco ("Es usted mi tío") y reitera su distanciamiento del sujeto ("señor"). Con lo cual este acto de comunicación ha convertido a los sujetos en referente puesto a prueba por su mutua identidad conflictiva. Las otras funciones se resuelven desde la situación identificatoria, que es previa a la estabilidad del circuito para la transmisión de información, pero completa en sí misma; y en este caso sin solución de continuidad porque el destinatario rechaza el papel moral de su emisor ante la información, lo ha sancionado con una identidad no gennina. Si ante el pongo buscaba él establecer esta identificación como el reconocimien to de un papel gennino de los sujetos en el habla, ante su tío, en cambio, convierte esta identificación en un metadiscurso de rechazo.

Revela la estratificación social y étnica el hecho de que esta estrategia se imponga como previa a la transmisión de mensajes, definiendo, tácitamente, la identidad valorativa de los sujetos. Lo cual implica su valor social, su valor de fuente, su valor étnico y, por eso, su misma capacidad para cumplir la comunicación en uno y otro discurso en los distintos tipos de discurso que corresponde a la naturaleza de hablante que socialmente marca a cada sujeto. La novela revelará justamente el drama de esos discursos en una tipología del habla estratificada, esto es, de la información mediatizada. Es obvio que la comunicación está situada socialmente pero que lo esté al punto de decidir una jerarquía valorativa de la información, una estimación sancionadora de los sujetos y una percepción normativa del sentido, al punto de reforzar y reproducir las formas de la violencia estructural de una sociedad, es revelador de la persuasión crítica de esta novela, que nos conduce hacia el "texto social" con la convicción de su denuncia radi- 
cal. Esa denuncia cuestiona la misma existencia social desgarrada por su violencia constitutiva. Y no es sólo moral: está enraizada en las alternativas latentes en esa existencia social, y busca legitimar la capacidad de respuesta de una percepción no sólo andina, sino peruana; es decir, una percepción cuya base andina ha incorporado una ampliación de información hispánica. Por ello, ver en Arguedas un autor indigenista o regionalista es empobrecer la calidad excepcional de su empresa, mucho más amplia y más fecunda. En este sentido, José María Arguedas enfrentó en su escritura algunos dilemas que también el Inca Garcilaso de la Vega, Guamán Poma de Ayala y César Vallejo habian hecho suyos. Definir un instrumento de la comunicación para transformar la comunicación, o sea, convertir a la escritura en una producción de comunicación reformulada, fue uno de esos dilemas que informan la tipología del tex to que debieron reconstruir para su empresa. Por eso, Arguedas no sólo es el narrador peruano más valioso de este siglo, sino que su trabajo reformula las mismas relaciones de la literatura y la cultura en un tex to que amplía sus funciones con el poder de sus convocaciones.

La experiencia del Cuzco significa para Ernesto la clausura de un espacio patriarcal legendario, y el recomienzo del viaje errante que subraya su carácter de figura desplazada, de conciencia flotante, de adolescente sin hogar y lugar socialmente determinados. (Hasta cierto punto, este esquema reproduce la biografía misma del autor ${ }^{13}$ ). Por otra parte, la afirmación de un modelo original de percepción se remonta a la infancia de Ernesto, a su primer ordenamiento del mundo en el sistema de comunicación plena que los comuneros tutelares le han revelado. En el Cuzco, las pautas de esa formación son confrontadas ya que deben resolver la nueva información socialmente jerarquizada. De la mano de su padre, cuya percepción de “caballero", de señor empobrecido, asimila el niño con sus pautas de nobleza e idealismo, resolverá el conflicto afirmando su propia percepción; y, sin duda, en la inminencia de que su destino social requerirá discernir una respuesta crítica y una opción participante. Como se ve, no es de un "personaje" de novela que se trata aquí: se trata, en el fondo, de la manifestación del sujeto multidimensional, de aquel "yo" que no se pronuncia a sí mismo pero que de un modo decisivo se manifiesta en la aventura constructora y crítica del texto. A ello volveremos luego.

La comunicación múltiple (escuchar el canto de las cosas, nombrarlas, hablarles, pero también interiorizarlas y discernir su sentido como un alfabeto descodificado) se abre en un espacio doble, típicamente ambivalente. Un espacio dichoso, otro de sufrimiento. El Cuzco mismo es doble: incluye los signos de un alfabeto fracturado y dominado, y los signos del código dominante. "En ningún sitio debía sufrir más la criatura humana"(24), concluye el texto. Los mismos edi-

13 Los textos autobiográficos de Arguedas requerirían una lectura detallađa. Véanse las noticias que él proporciona en "José María Arguedas", Historia y antología del cuento y la novela en Hispanoamérica, ed. A. Flores, 1959, pp. 503-504. Véanse también los textos de Arguedas reunidos por Juan Larco en su valiosa compilación crítica Recopilación de textos sobre José Maria Arguedas, La Habana, 1976, y sus intervenciones en Primer encuentro de narradores peruanos, Lima, 1969. 
ficios forman parte de un drama agónico y polar, incluso dentro del alfabeto dominante: las iglesias de la Compañía y la catedral, por ejemplo, mutuamente atenúan sus efectos. En la lectura de estos monumentos de las dos culturas, el padre y el hijo leen un discurso cósmico, escatológico y moral; y esta lectura está hecha desde una percepción que incluye las lecciones del mundo andino y las evidencias del mundo hispánico, percepción que podemos llamar aculturada pero sin suponer en ella una aculturación homogénea (lo que sería un mestizaje nivelador de ambas fuentes culturales), sino más bien una percepción sincrética, que en el niño parte de una estructuración de campos semánticos de estirpe andina.

\section{EL MODELO NATURAL Y EL MODELO SOCIAL}

\section{El canto del mundo}

Si el Cuzco (el "centro del mundo" para la cultura aborigen, el lugar sagrado) está usurpado por la figura del anti-padre, el avaro, quiere decir que el sentido se ha vuelto marginal y que su espacio sólo puede ser la errancia. Al salir otra vez de la ciudad, reaparece una figura natural protectora, contrapuesta a la fijeza ocupada: el movimiento libre, purificador del río. Significativamente, éste es el Apurimac, Dios que habla (26); y, en efecto, su nombre supone que el mismo mundo que recorre es una escritura dormida, que el río despierta y el viajero recibe. Escritura del mundo que se desdobla en escritura de la memoria: "La voz del río y la hondura del abismo polvoriento, el juego de la nieve lejana y las rocas que brillan como espejos, despiertan en su memoria los primitivos recuerdos, los más antiguos sueños" (26). Los ríos profundos corren en ese fondo mítico y original donde se alimenta la promesa de comunicación plena que define al peregrinaje del sujeto. "La voz del río aumenta; no ensordece, exalta", afirma el texto con su característica articulación de objeto natural (expresándose como un alfabeto que el interlocutor recibe) y sujeto definido por el acto físico de ese ritual cumplido. El nombre que sustantiva $^{14}$ en quechua, la traducción que subraya esa sustancia, $y$ la enunciación que convoca al objeto comunicante, son parte de ese ritual: "iApurimac mayu! iApurimac mayu! repiten los niños de habla quechua, con ternura y algo de espanto" (26).

En el espacio abierto (cap. 2, "Los viajes"), luego de la inmersión en el espacio cerrado del Cuzco, donde el universo simbólico del aprendizaje ha interiorizado las primeras evidencias, el "narrador-

\footnotetext{
14 Véase el trabajo de LOTMAN y USPENSKIJ, "Myth-name-culture", en la antología citada de Daniel P. Lucid, pp. 233-252.
} 
testigo" recuenta la bio-grafía del "narrador-actor". Esos viajes suponen la ausencia del hogar ("Mi padre no pudo encontrar nunca dónde fijar su residencia"'(27); pero el recuento fija la comunicación plena favorecida por un mundo que no cesa de hablar: entre los árboles, "quien busca sombra... reposa bajo un árbol que canta solo, con una voz profunda en que los cielos, el agua y la tierra se confunden"(27). La dispersión de la errancia se modifica, por ello, en el recuento del sentido percibido en este diálogo realizado. Es interesante que el viaje al Cuzco había sido decidido por el padre para cumplir un "proyecto" de venganza contra el Viejo; no se nos dice cuál fue ese proyecto incumplido, pero en el plano simbólico del relato es posible deducir que se cumple, en cambio, el aprendizaje iniciático del hijo, uno de los orígenes del tex to recusador. La incorporación de la misma errancia del padre al sentido del texto implica un reordenamiento profundo que la ficción trabaja. Esta transmutación que el texto produce se sostiene sobre otra, que el actor cumple oscuramente: en uno de los pueblos donde se detuvieron, uno donde odiaban a los forasteros, son sitiados por el silencio hostil de las gentes; el niño, en respuesta, escribe unos carteles: "Clavé en las esquinas unos carteles en que me despedía de los vecinos del pueblo, los maldecía”(30). Otra vez, canta en una esquina para una muchacha: "Varias noches fui a esa esquina a cantar huaynos que jamás se habían oído en el pueblo"(30) y también: "Me desahogaba; vertía el desprecio amargo y el odio con que en ese pueblo nos miraban, el fuego de mis viajes por las grandes cordilleras, la imagen de tantos ríos. .."(31). Estas expresiones de la soledad, de la comunicación incumplida, son también resueltas en el recuento que restaura el sentido en las articulaciones del texto.

Este canto del mundo a través del huayno se reproduce en el huayno guerrero que cantan los indios (33) desafiando a las aves de presa y sus batallas. El canto interviene, así, en el drama de una naturaleza a la que busca asumir y resolver: comunicación que retorna sobre sí misma, circularmente, en un esquema mítico que reafirma un orden suficiente. En cambio, en el pueblo donde los "notables"(32) matan loros, el narrador trata de alertarlos y espantarlos, sin suerte. Es evidente que el lugar del sujeto en el mundo natural supone aquí dos percepciones distintas, dos ámbitos vividos polarmente. La epifanía del pasaje no es sólo una transmutación mágica (una proyección del deseo que trueca al objeto en mediador), sino una previa comunión del sujeto en el objeto; es decir un recorrido del objeto iluminando al sujeto. Ese recorrido revela la capacidad de una percepción para reconocer la sustancia del sujeto en su estado de exaltación, de dicha, que es una comunicación extremada. Así, la repentina luz de una estrella transfigurando el paisaje (34), anuncia no sólo la emoción de la belleza ("Mi corazón latía como dentro de una cavidad luminosa" (34), sino también una traza que nutre la eficacia del código: 
“' 'iLucero grande, werak'ocha, lucero grande!', llamándonos, nos alcanzó el peón; sentía la misma exaltación ante esa luz repentina"(34). La luz, como el canto, como la voz, alimentan la circularidad mítica que se establece entre el referente y el código para la equivalencia sustantiva entre el nombre y la cosa.

Pero el espacio indistinto del viaje debe cerrarse en el programa de la novela: el aprendizaje requiere una segunda instancia, más compleja, más directamente confrontadora de las categorías de la socialización. Si el programa ha debido plantear el retorno al perdido paraíso patriarcal, y hacer explícito el ámbito discontinuo de la errancia, debe ahora precisar el conflicto más amplio, el relato de las peripecias de Ernesto en el colegio religioso y de sus exploraciones del pueblo de Abancay. "Viaje", "estudios", "rebelión" y "peste" son las grandes instancias del programa que el sujeto deberá resolver desde el relato del aprendizaje, y que el texto deberá articular como una lógica demostrativa del conflicto; en este caso, la socialización será puesta en conflicto por la disputa de modelos alternativos que el drama de la comunicación muestra sensiblemente. Después veremos que la formación del sujeto propondrá, ante la ambivalencia que discierne en el programa, uno diferente, capaz de cuestionar el contrato (familiar, religioso, educacional, nacional) que la socialización le impone. Otro programa y un contrato alternativo serán producidos por el texto en la deconstrucción que hace del modelo institucionalizado por la sociedad nacional y los aparatos ideológicos del Estado, y en la paralela construcción de una opción cultural que es crítica e impugnadora.

\section{Código español, código quechua}

De manera característica, el "narrador-testigo" informa del significado quechua (o sea, natural: sugiere flor y vuelo) de Abancay que, sin embargo, ahora "Es un pueblo cautivo, levantado en la tierra ajena de una hacienda" (36). Y en efecto, la condición cautiva del lugar, que reproduce el cautiverio del pupilo en el internado, y que hace eco al cautiverio del orden tradicional en el Cuzco, supone una serie de inclusiones de un espacio cerrado dentro de otro espacio cerrado. En primer término, la hacienda Patibamba rodea al pueblo de Abancay: esto es, el pueblo depende de su sistema económico y social, es tributario de aquél. En segundo término, el internado es un espacio recluido y es, además, un colegio religioso. La iglesia es otro espacio reglamentado y su vínculo con el colegio hace que ambas instituciones funcionen como aparatos ideológicos reproductores del orden pre-establecido por el sistema económico de la hacienda (semi-feudal y pre-capitalista, autoritario y patriarcal); orden naturalizado y sancionado como legítimo por la sociedad nacional y su Estado represivo $^{15}$. Ya esta distribución del espacio físico y simbólico ilustra

15 Sobre la hacienda, la comunidad indígena y sus relaciones con la sociedad nacional, 
la violencia de la dominación. El texto precisa estos signos para, enseguida, postular la fisura en este espacio, su desgarramiento. Primero, a partir del espacio polar, el barrio alegre de las chicherías; segundo, desde la actividad disolutiva, no codificable según el código establecido, que Ernesto y su rebeldía van a introducir; tercero, la rebelión y la peste serán otras subversiones de ese espacio oficial.

La introducción del adolescente al pueblo es sintomática: su padre le anuncia que el director del colegio, el padre Linares, es "un santo, que es el mejor orador sagrado del Cuzco y un gran profesor de Matemáticas y Castellano"(37). Su autoridad es religiosa, oral, intelectual y gramatical: representa, así, la institucionalidad etnocentrista de la cultura hispano-occidental, el poder del espíritu y el de la letra, la palabra autorizada y la lógica de la escritura. En cambio, la escritura como servicio de la ley agoniza en la figura del notario cuya cortesía de hidalgo pobre hace eco a la hidalguia desamparada del padre (quien también había sido "escribiente" en las haciendas del Viejo), un abogado trotamundos que no ha "oficializado", o institucionalizado, su profesión. La ceremonia de la comunicación gentil entre el visitante inoportuno (el padre), que no quiere ofender, y las atenciones del antiguo amigo empobrecido (el notario), anuncian el código de la cortesía tradicional, refinado aquí por el dolor de una hospitalidad y un afecto sin recursos.

La separación (cap. 3: "La despedida"), que se hace inminente, dividirá un diálogo autosostenido (la comunicación padre-hijo, que suponía un yo común, un nosotros sustantivo); diálogo que conllevaba, asimismo, un dominio armónico del medio: "Porque cuando andábamos juntos el mundo era de nuestro dominio, su alegría y sus sombras iban de él hacia mi"'(38-39). Diestramente, el "narradorautor" trasladará la escena de la despedida a la perspectiva del padre, siguiendo sus reacciones frente al "narrador-actor". La escena se produce cuando el padre celebra con el hacendado de Chalhuanca su nueva asociación, con lo cual su partida y la despedida se anuncian al mismo tiempo. Con no menor destreza, el episodio muestra al padre y al amigo en copas: ello posibilita que el habla ingrese a otro tipo de discurso, más libre y más afectivo. Por eso, cuando el padre finalmente llora, leemos: "El chalhuanquino pretendió consolarlo; le hablaba quechua, ofreciéndole todas las recompensas y los mundos que en el idioma de los indios pueden prometerse, hasta calmar por un instante las grandes aflicciones"(41).

El idioma de los indios muestra aquí uno de sus rasgos: comunicarse en él es acentuar la función expresiva para mejor convocar la función connotativa o apelativa. El emisor acude al quechua para decir

JULIO COTLER, "Haciendas y comunidades tradizionales en un contexto de movilización política" en Realidad nacional, ed. J. Ortega, Lima, 1974, t. 1, pp. 335-365; La hacienda, la comunidad y el campesino en el Perú, Roberto G. Keith et al., Lima 1970; y El indio y el poder en Perú rural, Fernando Fuenzalida et al., Lima, 1970. 
más y recuperar al destinatario en un referente verbalizado como emotividad. Es evidente que el quechua (por su carácter de fuente coinformativa, por su reserva sustantivadora) manifiesta la comunicación que corresponde al primer paradigma, al modelo del comunicar natural. Siendo una lengua oral, y a la vez una lengua socialmente marcada, su aparición se produce como un desnudamiento cultural: revela el "ser natural", original, de los hablantes; y por ello mismo, su función expresiva es a la vez apelativa. En el quechua habla un "yo" que busca enunciarse como un "nosotros": en el acto mismo de su presencia se manifiesta la identificación de los hablantes ${ }^{16}$. Ahora bien, si parece evidente que la oralidad del quechua sostiene su comunicabilidad valorativa, su fuente de identidad, no es menos cierto el hecho de que en el texto el quechua cumple otras funciones comunicativas. En primer término, provee un origen lingüístico, etimológico, como un repertorio subyacente del sentido; esta forma verbal del sentido es, claro, una fuente textual. En segundo término, desdobla el relato en el discurso: el texto acude a las mediaciones del quechua (en el diálogo y en las canciones) no sólo como testimonio del mundo indígena, sino como la auto-expansión del texto desde su bilingüismo. En tercer término, el quechua es una lengua oral que aquí posee, sin embargo, otra escritura: el alfabeto del mundo. En efecto, esta característica tradición literaria del mundo como escritura (tan presente en la literatura latinoamericana ${ }^{17}$ ), se sustenta aquí en la materialidad y la calidad motivada que el texto confiere a una lengua oral, que desde el texto dice las relaciones del sujeto y su ámbito, sustantivando las interacciones de los hablantes en su cultura.

Pero si esta fuente de la comunicación como ganancia del mundo se limitara sólo a sus hablantes, la versión sobre las posibilidades de comunicar que el texto produce sería parcial. Precisamente, la empresa del texto es que su versión busca ser más comprehensiva: la lengua quechua y la lengua castellana se funden no en un tercer idioma sino en un texto plurilingüe. Esto quiere decir que sobre la fuente quechua y sus funciones identificadora y apelativa, el instrumento caste-

16 Sobre el bilingüismo peruano es fundamental el trabajo de A LBERTO ESCOBAR, JoSÉ MAtos MAR y GIORgIo ALBer TI, Perú, ¿país bilingüe?, Lima, 1975. Véase también la compilación de Escobar, El reto del multilingüismo en el Perú, Lima, 1972, y su libro Lenguaje y discriminación social en América Latina, Lima, 1972; ALFREDO TORERO, El quechua y la historia social andina. Lima, 1974; SARA CASTRO-KLAREN, "Mundo y palabra; hacia una problemática del bilinguismo en Arguedas", Runa (Lima), 1977, núm. 6, p. 8.

$17 \mathrm{El}$ tema está por estudiar, tanto en sus vinculaciones con la tradición literaria como en sus posibles revisiones y actualizaciones. Es visible en Vallejo y Neruda, en Paz y Lezama, en Cortázar y Enrique Molina. La idea común de que la representación del mundo es una "naturaleza", un "paisaje", en lugar de un modelo desde la escritura, ha impedido una mejor comprensión de la funcionalidad de esa representación. Las relaciones del objeto y del nombre son más interesantes que la transcripción un tanto "primitiva" que se le ha atribuido a Arguedas. Por lo pronto, William Rowe ha visto bien que la disyunción de Saussure entre el significante y el significado dentro del signo, no es pertinente en la escitura de Arguedas; véase su trabajo "Mito, lenguaje e ideologia como estructuras literarias", Recopilación de textos sobre José María Arguedas, ed. J. Larco, pp. 257-283. 
llano ampliará sus funciones, ganando con ello la resonancia y la tensión de un decir religado, de un escribir producido como polifonía de un espacio de conjugaciones y disyunciones; un espacio cultural que es eminentemente textual. En su juventud, José María Arguedas había pensado escribir en quechua, y luego decidió fabricar una lengua castellana que incorporara ciertos ritmos sintácticos y cierta entonación del quechua, que, en efecto, es el substrato de su trabajo con el lenguaje ${ }^{18}$. Por eso se podría decir que "nadie habla" como en los libros de Arguedas, pero que su lenguaje es del todo equivalente; primero, una translación del quechua a un castellano singular; después, un castellano modulado y organizado para una percepción y registro del decir distinto. De allí que algunos lectores hayan resentido, por ejemplo, el discurso de la emotividad que las normas del castellano recortan en otro tipo de discurso, y que las del quechua elaboran más abiertamente. Pero este "decir más", esta entrega a la enunciación, a la posibilidad de "decirlo todo", no deriva sólo de la necesidad de recobrar un tipo de discurso expansivo de las emociones, implica una percepción central de esta novela: la necesidad de reelaborar un sistema de comunicación plural. La producción misma de la escritura sostiene un nuevo tipo de revelación comunicativa. La discusión acerca de si el texto literario es comunicación o producción no parece pertinente en el caso de los textos de Arguedas: estos textos postulan la productividad textual desde una reelaboración comunicativa. Texto y comunicación se explican mutuamente, y mutuamente sustentan su diferencia literaria y su incidencia cultural ${ }^{19}$.

He aquí la empresa original de José María Arguedas: producir un texto sobre la comunicación, dramatizando su existir social y reelaborando su latencia identificatoria. Además, producirlo con los materiales discordantes de, justamente, una situación de fractura en la comunicación, de estratificación del habla y de violencia sobre la libertad de decir. El texto genera así su postulación utópica: una comunicación realizada; la que denuncia el drama de hablar en el Perú,

18 Lo ha explicado el propio Arguedas en el Prólogo a Diamantes y pedernales, Lima, 1954. John Murra cuenta que Arguedas cambió sus planes de escribir en quechua ante la persuasión de su amigo, el mexicano Moisés Sáenz, que fue embajador en Perú durante el gobierno de Cárdenas; en sus últimos años, Arguedas lamentó esa decisión temprana; ver J. Murra, "Introduction" a Deep rivers, trad. de F. Horning Barraclough, Austin, 1978.

${ }^{19}$ Un buen resumen de esta discusión es el de MARC ZIMMERMAN, "Exchange and production: Structuralist and Marxist approaches to literary theory", Praxis (California), 1979, núm. 4, pp. 151-168. Véase también ROBERT ESCARPIT y CHARLES BOUAZIS, Systèmes partiels de communication, Paris, 1972; PIERRE MACHEREY, Pour une théorie de la production littéraire, Paris, 1966. Plantean nuevas perspectivas los excelentes trabajos de JEAn BAUDrillard, Pour une critique de l'économie politique du signe, Paris, 1972, y JEAN-JosePH GoUx, Freud, Marx, économie et symbolique, Paris, 1973. Un aporte semiótico a partir de Greimas y Derrida es el de CHARLEs BouAzis, Littérarité et société. Théorie d'un modèle du fonctionnement littéraire, Paris, 1972, y del mismo Bouazis, "Le problème du système scientifique de la communication", en el libro citado de Escarpit y Bouazis, pp. 213-225. 
en cualquier sociedad represiva, agudizándolo con su recusación de los órdenes de la violencia ${ }^{20}$.

\section{Función e identidad de los hablantes}

Una forma especialmente aguda de violencia es la que se ejerce en contra de la comunicación. Si hiciéramos una tipología de la violencia en el Perú (o, para el caso, en América latina) nos veríamos obligados a incluir este tipo de violencia sobre la comunicación que Arguedas descubre, y que es central a su percepción de la injusticia ${ }^{21}$. En efecto, luego de que el "narrador-testigo" (cap. 4: "La hacienda") nos ha proporcionado una caracterización del hacendado, y después de que las tres voces del Narrador han diseñado el espacio cerrado de Abancay, la actualidad de la acción nos enfrenta con las consecuencias de la estratificación:

Los indios y las mujeres no hablaban con los forasteros.

-Jampuyki mamaya (Vengo donde ti, ¡madrecita!) -llamé desde algunas puertas.

- 'Mánan! ¡A ma rimawaychu! (¡No quiero! ¡No me hables!) -me contestaron.

Tenía la misma apariencia que el pongo del Viejo (...)

- iSeñoray, rimakusk'ayki! (¿Déjame hablarte, señora!) -insistía, muchas veces, pretendiendo entrar en alguna casa. Pero las mujeres me miraban atemorizadas y con desconfianza. Ya no escuchaban ni el lenguaje de los ayllus; les habían hecho perder la memoria; porque yo les hablé con las palabras y el tono de los comuneros, y me desconocieron (45).

El diálogo es paralelo al que Ernesto sostuvo con su tío: la situación, también aquí, es identificadora. En este caso, el emisor demanda ser identificado con los signos del reconocimiento con que él está identificando al destinatario; pero, como antes frente al pongo, la

20 Acerca del "drama de hablar en el Perú", presento un análisis más amplio en mi artículo "Crisis, identidad y cultura en el Perú", Perú: identidad nacional, ed. C. Arróspide de la Flor et al., pp. 191-208; y en mi libro La cultura peruana: experiencia y conciencia, México, 1978.

${ }^{21}$ Sobre la tipología de la violencia, véase JoHAN GALTUNG, "Violence, peace, and peace research", Journal of Peace Research (Oslo), 1969, núm. 3, 167-191. Galtung presenta el concepto de "violencia estructural", la que se mide por el promedio de vida de los ciudadanos de un país, y que se origina en la injusticia social. Además de ésta, los países latinoamericanos padecen estos otros tipos de violencia: la "legítima" (que usa el Estado, según la definición de Weber, y que es menos legítima en nuestros países porque su base no supone un consenso auténtico); la represiva (que el Estado emplea, demostrando su ilegitimidad, y que se expresa mejor a través de la tortura institucionalizada); la institucional (que se expresa en lo que Althusser llama los aparatos ideológicos de Estado, y supone la práctica de la socialización como una forma idcológica de la represión); véase CARLOS AMAT DE LEÓN, "La disiribución del ingreso familiar en el Perú", Socialismo y participación, Lima, 1978, núm. 2. pp. 9-41. En la lucha por la inform ación que define al conflicto social desde la perspectiva de la cultura, es visible otro tipo de violencia: la descomunicación, que los medios de comunicación promueven al presentar información según los intereses de clase de la sociedad nacional y el aparato del Estado. Véasc JULIo ORTEGA y CECiLIA BustaMANTE, "Para una tipología de la violencia", Sábado, "Unomásuno", México, 10 de enero de 1981 . 
convocación no se cumple. Aún más, en este caso es rechazada: estos indios se revelarán todavía más sometidos que el pongo del Cuzco. El rechazo de la comunicación equivale a la pérdida de la identidad ("memoria"); o sea, al vacío cultural de la sumisión más violenta que pueda imaginarse. Su silencio no es sólo la forma de su miedo: es antes la marca de su lugar social.

Así desconocido, no reconocido, Ernesto comprueba que el modelo de la comunicación plena (el habla de los comuneros) ha sido aquí desarticulado. Esta fractura de su papel de emisor pone en duda su propia identidad: volvió al pueblo, leemos, "temiendo desconocer a las personas o que me negaran" (45). En el colegio, es identificado como "loco" y "tonto vagabundo". La crisis de su papel comunicante reproduce la zozobra de su identidad cultural, de su pertenencia a un orden que carece de substrato social suficiente y que, desde ahora, marca su marginalidad radical. La alienación del nuevo medio se expresa a través de la comunicación, que es la metáfora sensible de su destierro: "En esos días de confusión y desasosiego, recordaba èl canto de despedida que me dedicaron las mujeres, en el último ayllu donde residí, como refugio, mientras mi padre vagaba perseguido.

Huyendo de parientes crueles pedí misericordia a un ayllu que sembraba maíz en la más pequeña y alegre quebrada que he conocido. Espinos de flores ardientes y el canto de las torcazas iluminaban los maizales. Los jefes de familia y las señoras, mamakunas de la comunidad, me protegieron y me infundieron la impagable ternura en que vivo"(45-46).

Si Arguedas se hubiese limitado a ofrecernos la belleza del paisaje, imágenes como éstas probarían su eficacia pictórica; pero pasajes como éste demuestran que el medio (su representación) desempeña un papel más importante en el texto: forma parte del drama, actúa como su resonancia. Tampoco se trata de una mera arcadia infantil, natural o ecológica: la representación sostiene aquí a un modelo de la comunicación. Modelo que conjuga una escritura del mundo con un habla que transforma a los hablantes en una familia humana dentro de una morada plena. Modelo, por ello, activo, y proyectado como una actualidad crítica frente al otro modelo de la comunicación deprimida.

En esta escena, que ilustra el primer modelo, el relato no deja de introducir la fractura que define al sujeto (la errancia in fantil, el destierro adolescente, la búsqueda de una articulación simbólica en el adulto). El harahui (canción) de la despedida, que los indios cantan al niño, revela intensamente la plenitud y el drama de esta comunicación superior:

iNo te olvides, mi pequeño, no te olvides! Cerro blanco, hazlo volver, 
agua de la montaña, manantial de la pampa

que nunca muera de sed.

Halcón, cárgalo en tus alas

y hazlo volver.

Inmensa nieve, padre de la nieve,

no lo hieras en el camino.

Mal viento,

no lo toques.

Lluvia de tormenta,

no lo alcances.

¡No, precipicio, atroz precipicio,

no lo sorprendas!

¡Hijo mío,

has de volver,

has de volver! (46)

Esta canción quechua, cuyo original en esa lengua se incluye, resume bien la calidad apelativa del emisor colectivo de este hablar mítico. La función connotativa, imperativa, que es un reclamo y un conjuro, supone el mundo habitado por la proyección del deseo (magia), nombrado y humanizado en la ceremonia enumerativa (rito), aprehendido por la circularidad del ir/volver en el mismo acto del canto (mito). ¿Qué decir de la calidad emotiva de toda esta secuencia, de su refinamiento y ternura? Pocos autores han logrado esa pulsación, esa vibración comunicativa. Al hacer suya esta canción, el texto habla a través de una cultura.

Otro es el modelo de la comunicación de la sociedad dominante, establecido por la sociedad nacional y reproducido por los aparatos de estado que controlan la clase gobernante y sus delegados y aliados. La primera escena en el colegio ilustra ese sistema:

- ¡El dueño de Auquibamba! -decían los internos.

- ¡El dueño de Pati!

- ¡El dueño de Yaca!

Y parecía que nombraban a las grandes estrellas(47).

Al suprimir los nombres de los hacendados y presentarlos por su dominio sobre la propiedad, el texto muestra agudamente el funcionamiento por el que se identifica este modelo de la comunicación. Si el anterior se basa en la propiedad colectiva, éste se basa en la propiedad semifeudal. En lugar de nombres de propios su identidad requiere de los nombres del poder, su identidad está en la pirámide de la sociedad y del lenguaje. Este descubrimiento del orden establecido se hace a través de su sistema de procesar la información, y tiene, desde la percepción de Ernesto, su centro emisor en la figura del Padre Director, cuya presentación en el texto es un análisis de su papel comunicativo.

El Padre Director empezaba suavemente sus prédicas. Elogiaba a la Virgen con palabras conmovedoras; su voz era armoniosa y delgada, pero 
se exaltaba pronto. Odiaba a Chile y encontraba siempre la forma de pasar de los temas religiosos hacia el loor de la patria y de sus héroes. Predicaba la futura guerra contra los chilenos. Llamaba a los jóvenes y a los niños para que se prepararan. . . Y así, ya exaltado, hablando con violencia, recordaba a los hombres sus otros deberes. Elogiaba a los hacendados; decía que ellos eran el fundamento de la patria, los pilares que sostenían su riqueza. Se refería a la religiosidad de los señores, al cuidado con que conservaban las capillas de las haciendas y a la obligación que imponían entre los indios de confesarse, de comulgar, de casarse y vivir en paz, en el trabajo humilde (47).

El pasaje es explícito: éste es un emisor que suma la autoridad del discurso religioso y del discurso oficial y estatal al de la autoridad específica. Es un emisor privilegiado: su discurso es el de la ideología dominante, de allí que sea jerarquizador, normativo y sancionador desde el sistema. De allí también que su forma sea la violencia. Por lo demás, la suma de elementos en esta escena (autoridades, hacendados, iglesia, colegio) anuncia la actividad altamente codificada de los aparatos ideológicos en la pequeña ciudad provinciana que funciona como un modelo condensado de la sociedad nacional. Pero si el Padre Director solamente fuese un representante "negativo" de la cultura dominante, el texto perdería la especificidad del conflicto; ocurre, más bien, que este oponente privilegiado es una figura ambigua: es una figura patriarcal cuyo papel moral y cuya autoridad en la información deberán todavía ser puestos a prueba. Son las opciones frente al desarrollo conllictivo del relato lo que decidirá la capacidad resolutiva, y la dimensión ética, de los modelos en disputa.

El único espacio abierto dentro del espacio cerrado de Abancay (el barrio de Huanupata), introduce nuevos signos en el debate (cap. 5: "Puente sobre el mundo"). Es un barrio vinculado al mercado, donde están las chicherías. Espacio antioficial, en él se conjugan indios, cholos y mestizos: barrio "alegre", lugar de intermediación étnica y social, es un espacio de activa comunicación. Entre los indios siervos y campesinos y los mestizos y señores de la ciudad, este lugar es un tercer ámbito social: no parece señalar una mera instancia de transición entre uno y otro estrato étnico y social; parece, más bien, un estrato propio: el que corresponde, precisamente, a la intermediación y al intercambio, a la cultura popular del mercado; en parte, al estrato cholo de la sociedad peruana ${ }^{22}$. Es revelador el que este espacio cultural abra una de las alternativas dinamizadas por el conflicto: la rebelión de las chicheras. También es interesante que sean las mujeres, cuyo papel intermediario es más intenso, quienes lleven a cabo esa ruptura del sistema.

Por lo pronto, el canto es aquí una primera forma comunicativa.

22 Francois BoUrRicaud, "Indian, mestizo and cholo as symbols in the Peruvian system of stratification", en Ethnicity, theory and experience, ed. N. Glazer y D. P. Moynihan, Cambridge, Mass., pp. 380-387; M. DAvis, JR., Indian integration in Peru, 1900-1948, Nebraska, 1974. 
Los viajeros piden a los músicos huaynos de sus regiones, pero al ser interpretados adquieren el ritmo de la música de Apurimac. Los ritmos, las entonaciones, son distintos según los pueblos, y señalan la identificación regional, que es una marca muy fuerte en una sociedad desarticulada nacionalmente. Incluso en los huaynos de regiones desconocidas, es perceptible el carácter del lugar, que actúa como verdadero emisor. Así, las mestizas sólo cantaban huaynos "de la tierra donde crecen la caña de azúcar y los árboles frutales" (50), y a través de sus voces un paisaje distintivo se manifiesta. Notoriamente, los "indios de hacienda" no concurren a este lugar: "Deseaba hablar con ellos y no perdía la esperanza. Pero nunca los encontré"'(51), se nos informa; la dominación que los sentencia al silencio es también un cerco físico que les impide acceder a este espacio de afirmación y reconocimiento.

En cambio, en el espacio del colegio y bajo la autoridad del Director, padre simbólico del sistema, el sujeto requiere participar en un ritual de representaciones y enmascaramientos que son el proceso de un reconocimiento sustitutivo y diferido. A través de este ritual buscará afirmarse la individualidad, el "yo" como una marca diferenciadora sobre el "nosotros". Y este proceso de la identidad no podrá darse sino en un clima de violencia: de autoviolencia y de violencia mutua. El sujeto se reconocerá, de ese modo, en los accidentes y tormentos de un "yo" siempre confrontado. El sentimiento de culpa, la humillación, el enmascaramiento, convertirán a la comunicación en un laberinto, en una trampa. De allí el tormento de Ernesto: los códigos entran en crisis, y su subjetividad herida exacerba la información que recibe y que lo confronta. Por lo mismo, su conducta se hará extraña: sus códigos son otros, y la percepción de las autoridades del colegio y de varios de sus compañeros no logrará situar, hacer legible, ese comportamiento "desadaptado".

Ya los juegos adolescentes son un síntoma de la violencia latente del discurso oficial: una pelea franca entre "chilenos" y "peruanos"; y, en última instancia, una máscara de la identidad. "Y los odios no cesaban, se complicaban y extendían" (55), resume el texto. Una víctima señalada de esta violencia será Palacios, cuyo origen campesino se delata en su falta de control del instrumento de dominio, la escritura: "Leía penosamente y no entendía bien el castellano"(57). Otra víctima es el Peluca, el cobarde, quien al optar por el aislamiento "exasperó a los internos. Y lo atacaron, una noche en el patio interior"(63). Es interesante la razón para atacarlo: "-Ya no nos oye el Peluca-se quejaron varios"(63), o sea, esta violencia es una forma de comunicación distorsionada. A partir de la culpabilidad de las experiencias eróticas con una demente que, por cierto, no habla, esta violencia culmina en acusaciones y desgarramientos que afligen al sujeto y lo llevan al arrepentimiento. El Padre Director conoce bien estas expiaciones recurrentes: "se sintió muy satisfecho del sollozo intenso de los 
alumnos"(64). Es previsible, por lo demás, la misma división del espacio dentro del colegio: hay un patio empedrado "donde cantábamos huaynos jocosos y alegres"(65), y otro oscuro a donde concurre la demente. Frente a esta experiencia del eros como impureza y, sobre todo, ausencia de comunicación, Ernesto levanta la imagen de otra relación, basada en un dar y comunicar plenos: "alguna. . . que pudiera adivinar y tomar para sí mis sueños, la memoria de mis viajes, de los ríos y montañas que había visto..."(65). El patio oscuro implica un espacio perverso, contaminado, que hiere al sujeto y lo separa y aísla: "a la hora en que volvía de aquel patio, al anochecer, se desprendía de mis ojos la maternal imagen del mundo. Y llegada la noche, la soledad, mi aislamiento, seguía creciendo"(66). Desamparado de su identidad, de una comunión maternal, sobre él se cierne como la culpa esa separación de las fuentes tutelares que modelan su información. Por lo tanto, su culpa es de otro orden: no es religiosa sino mítica; es contra el orden natural que ha "pecado".

Esta separación de las fuerzas sustentadoras le evoca de inmediato el abandono que padeció de niño: "Lo recordaba, lo recordaba y revivía en los instantes de gran soledad; pero lo que sentía durante aquellas noches del in ternado, era espanto, no como si hubiera vuelto a caer en el valle triste y aislado de Los Molinos, sino en abismo de hiel, cada vez más hondo y extenso, donde no podía llegar ninguna voz, ningún aliento del rumoroso mundo" (67).

Es, pues, la comunicación con ese remitente incesante, el "rumoro. so mundo", lo que se ha fracturado. Los domingos, Ernesto busca esas voces y baja en pos del río entre las plantas que "cantan como sonajas"(67). Sobre el gran río hay un bello puente, "construido por los españoles": "Yo no sabía si amaba más al puente o al río. Pero ambos despejaban mi alma, la inundaban de fortaleza y de heroicos sueños. Se borraban de mi mente todas las imágenes plañideras, las dudas y los malos recuerdos.

Y así, renovado, vuelto a mi ser, regresaba al pueblo; subía la cuesta con pasos firmes. Iba conversando mentalmente con mis viejos amigos lejanos: don Maywa, don Demetrio Pumaylly, don Pedro Kokchi. . . que me criaron, que hicieron mi corazón semejante al suyo" (68).

Este acto de purificación ritual restituye la convicción del modelo natural como paradigma de una comunicación superior, donde la formación básica se ha cumplido y desde donde la información es percibida. Desde aquí deberá levantarse el mismo futuro: el sujeto, se nos dice, "Debía ser como el gran río: cruzar la tierra, cortar las rocas; pasar, indetenible y tranquilo, entre los bosques y montañas; y entrar al mar, acompañado por un gran pueblo de aves que cantarían desde la altura" (68). Es la convicción de una cultura, con su racionalidad propia, tan legítima como otra cualquiera, la que se propone aquí una topología de su sentido. 
Desde esta perspectiva interiorizada, el "narrador-testigo" retorna (cap. 6: "Zumbayllu") para dramatizar en su informe la lengua de ese modelo: otra vez una discusión lingüística sobre el quechua y su manifestación del logos. Ahora se nos presenta un repertorio de instrumentos de esta comunicación sustantivadora, que incluyen la música, la voz y la luz. En este repertorio de mediadores mágicos, que reciben, transmutan y proyectan el deseo de la comunicación plena, se sitúa el trompo, el zumbayllu, como figura del juego ritual y el deseo transfigurador. Objeto iniciador de un diálogo nuevo, liberador, el mágico trompo renueva el espacio, lo hace propicio, y restituye una condición original a los jugadores o celebrantes. "El canto del zumbayllu se propagó con una claridad extraña; parecía tener agudo filo" (74); "El canto del zumbayllu se internaba en el oído, avivaba en la memoria la imagen de los ríos"(75). Antero, el muchacho que ha fabricado el trompo, es llamado el "Markask'a", por sus lunares; su singularidad "algún poder tenía, alguna autoridad innata"(77) lo distingue del grupo, de modo paralelo a la singularidad de Ermesto, que es calificado de "poeta" y escribe cartas de amor por encargo de sus compañeros, marca de su propia autoridad escriptural. También los trompos tienen su propia marca: "Esta noche te haré un zumbayllu especial. Tengo un winku, cholo. Los winkus cantan distinto. Tienen alma", le dice Antero a Ernesto; y el texto añade a pie de página que winku significa "Deformidad de los objetos que debían ser redondos"(78). Incluso los trompos reconocen esta marca descentrada, disforme.

Una carta de Ernesto para la novia de Antero derivará hacia otra carta, dirigida a las muchachas campesinas de la infancia comunitaria. "¿Y si ellas supieran leer? ¿Si a ellas pudiera yo escribirles?”(81), se pregunta el "narrador-actor". "Si yo pudiera escribirles, mi amor brotaría como un río cristalino; mi carta podría ser como un canto. . " La escritura no reemplaza a la canción, a la voz. "iEscribir! Escribir para ellas era inútil, inservible"; debería, se dice, esperarlas en los caminos y cantar. Sin embargo, lo intenta: en quechua unas palabras, en castellano (implicando una traducción) enseguida. Como en el huarahui de la despedida, aquí los sentimientos se dicen con los nombres mediadores del mundo natural. Esta exaltación comunicativa lo pone nuevamente en contacto intenso con la certidumbre del propio modelo: llora de emoción, y se siente poseído por "un seguro orgullo"(82). Puesto a prueba, el modelo de una cultura alimenta al sujeto con su reserva de comunicación protectora, que todavía deberá ser dramatizada por otros ritos de la socialización en la cultura dominante en la cual, necesariamente, el sujeto deberá internarse para ampliar sobre ella su modelo original que irá así forjando su validez universal, su legitimidad alternativa. Un rito es la lectura en voz alta ("Fueron esas lecturas públicas las que me dieron prestigio" 82), del Manual de Carreño, una de las codificaciones más sistemáticas del modelo de conducta hispánico tradicional; otro rito es el 
desafío y la pelea. Es a esta altura que Ernesto es marcado desde la codificación más usual: le llaman "indiecito" y "cholito" (83). También a esta altura, el texto va convirtiendo al 'relato del aprendizaje' en 'novela del arte': este retrato del artista adolescente andino no es menos exploratorio que aquel otro del adolescente irlandés; aunque aquí la "conciencia de mi raza" no está "increada": existe como una forma realizada, si bien socialmente negada. Nuestro artista se confrontará con Valle, el "intelectual" del relato, "el único lector del Colegio"(84), pero cuyo lenguaje "“atildado", "a causa de sus lecturas"(85), lo revelerá como un manipulador frívolo del lenguaje. En la noche previa al combate con Rondimel, que Valle ha calificado de "nuevo duelo de las razas"(86), de nuevo la comunicación dual se ofrece a Ernesto, pero su opción es ciertamente previsible: "Por la noche, en el rosario, quise encomendarme y no pude. La vergüenza me ató la lengua y el pensamiento.

Entonces, mientras temblaba de vergüenza, vino a mi memoria, como un relámpago, la imagen del $A p u \mathrm{~K}$ 'arwarasu. Y le hablé a él, como se encomendaban los escolares de mi aldea nativa, cuando tenían que luchar o competir en carreras y en pruebas de valor.

- iSólo tú, $A p u$ y el 'Markask'a'! -le dije - iApu K'arwarasu, a ti voy a dedicarte mi pelea!"'(87).

La "vergüenza" parece aquí una emoción del nuevo código, de raíz cristiana, cuya impotencia es vencida con la exaltación del otro código, apelando al cerro tutelar y a la demanda mágica de una protección. 'Los indios - añade nuestro informante - invocan al $\mathrm{K}$ 'arwarasu únicamente en los grandes peligros. Apenas pronuncian su nombre el temor a la muerte desaparece" (87). Un hombre más fuerte que la muerte: la proyección del deseo, la definición mágica, se cumple en el interior del código de esta cultura tradicional que modela a una comunicación mítica. Por eso, al final, otra ceremonia de purificación se impone: el trompo canta "por todos sus ojos" (94) y Ernesto le habla directamente: "- iAy, zumbayllu, zumbayllu! iYo también bailaré contigo!" (94). Tras la danza, la restitución del nosotros enriquecido se ha producido: “iNadie es mi enemigo! iNadie, nadie!" (94). El juego adquiere un sentido mayor, culmina en su verdadero destinatario, el nosotros solidario. "El sol alumbraba para él solo, esa mañana. El mundo redondo, como un juguete brillante ardía en sus manos. iEra de él! Y nosotros participábamos en la dicha de sentirlo dueño" (96). De este modo parabólico, por la comunicación ritualizada, el modelo de la cultura andina incorpora a los hablantes de la otra cultura en el consenso ampliado.

\section{La subversión del discurso}

Pero antes de tentar el diseño de esas ampliaciones, el texto requiere todavía resolver una prueba extrema de las relaciones de ambos 
modelos: la subversión de las chicheras (cap. 7: "El motín"). El motín se ha producido porque la Recaudadora (dependencia estatal de comercialización y captación de impuestos) que controla la distribución de la sal ha ocultado este producto esencial para los negocios de las chicherías. $\mathrm{Al}$ parecer, otras resonancias son posibles en esta rebelión popular por la sal. Tradicionalmente, antes de la conquista espanola, los indígenas de los valles interandinos controlaban las salinas de la costa; la usurpación por el Estado de ese control es otra expoliación de la cultura nativa. Por otra parte, la sal es un elemento esencial de la cultura popular, no sólo de los negocios de las chicherías, y, de alguna manera, es un elemento colectivo, cuya usurpación se revela antinatural. ¿No es, por último, un emblema sustantivo, terrestre y distintivo? Sin duda, esta densidad simbólica subyace aquí, señalando a una cultura intermediaria cuya rebeldía es una suerte de recuperación. No es casual que ésta sea una rebelión de las mujeres, de las madres. Pero, antes, estamos ante un motín muy específico, y en el cual Ernesto, y el mismo texto, ganará una participación comunicativa, que ya sabemos es una forma de dicha, y que será ahora una forma de crítica.

Esa cultura intermediaria es la de los cholos: su lengua quechua los identifica en su origen andino pero su capacidad de respuesta les da mayor movilidad incluso que a los mestizos, más dependientes del sistema occidentalizado. "La violencia de las mujeres me exaltaba. Sentía deseos de pelear, de avanzar contra alguien" (98), declara el narrador, ante el espectáculo de las mujeres que han ocupado la plaza, el centro del espacio oficial. Se trata, en primer lugar, de una ruptura de ese espacio y, consecuentemente, de su comunicación reglada: "Las ees suavísimas del dulce quechua de Abancay sólo parecían ahora notas de contraste, especialmente escogidas, para que fuera más duro el golpe de los sonidos guturales que alcanzaban a todas las paredes de la plaza" (98). Es este acto mismo de la subversión del sistema de comunicación establecido lo que exalta al muchacho. Otra simetría: los de la Recaudadora son calificados de "ladrones" y, como tales, su culpa social es comparable a la "avaricia" de los señores cuzqueños. Son culpas monstruosas que distorsionan el precario equilibrio de la existencia social, y que anuncian una distorsión previa y mayor, el sistema de dominación de castas y de clases. Por eso, las mujeres demandan la muerte de los culpables. En el drama, los protagonistas se vuelven a definir por su papel comunicativo:

Cuando volvieron a repetir el grito, yo también lo coreé.

El "Markask'a" me miró asombrado.

-Oye, Emesto, ¿qué te pasa?- me dijo. - ¿A quién odias?

-A los salineros ladrones, pues -le contestó una de las mujeres (99).

Sumarse al nosotros sublevado equivale a ceder la palabra a la respuesta común. En cambio, cuando el Padre intenta sofocar la re- 
belión apela, acudiendo al quechua, a otra fmente del nosotros: “-. . . No, hija. No ofendas a Dios. Las autoridades no tienen la culpa. Yo te digo en nombre de Dios"(99). El código de la religión como autoridad de la información ("- iNo me retes, hija! iObedece a Dios!"), sanciona también a la comunicación sublevada, cuyo origen es comunal: "En los pueblos de indios las mujeres guardan silencio cuando los hombres celebran reuniones solemnes. En las fiestas familiares, aun en los cabildos, los indios hablan a gritos y a un mismo tiempo. Cuando se observan desde afuera esas asambleas parecen una reunión de gente desaforada. ¿Quién habla a quién? Sin embargo existe un orden, el pensamiento llega a su destino y los cabildos concluyen en acuerdos" (102).

Allí las mujeres no cumplen el papel activo que ahora demuestran, y que se centra en torno a una dirigente popular, doña Felipa. Bajo su conducción, las mujeres asaltan la Recaudadora y empiezan a repartir la sal. Pronto la rebelión delata su carácter popular: "Entonces, una de las mestizas empezó a cantar una danza de carnaval; el grupo la coreó con la voz más alta"(103). El carnaval evidencia el sesgo cultural, que es a un tiempo crítico y festivo, una respuesta propia a los insultos y ataques de los vecinos. Frente a la casa-hacienda, "Las mujeres levantaron la voz, aún más, junto a las rejas"(104). Y ya junto a las rancherías donde viven los indios más pobres, y donde antes Ernesto había fracasado al intentar hablar a las mujeres, las rebeldes logran hacerlas salir para el reparto de la sal: "vinieron las mujeres, dudando aún, caminando muy despacio"(105). "Las indias recibían la sal, la bendecían con sus manos, se volvían a sus chozas, y se encerraban". La rebelión ha logrado, hasta cierto punto, fracturar su silencio y su pánico. La comunicación ganada se expresa como subversión radical: "Una sangre dichosa que se derramaba libremente en aquel hermoso día en que la muerte, si llegaba, habría sido transfigurada, convertida en triunfal estrella" (106).

Pero la rebelión fracasa: la represión es inmediata. En otra comunicación plena, con una mujer maternal que lo protege, Ernesto vive el drama agudizado de su aprendizaje: la ternura protectora de la mujer desconocida, la amargura de la derrota popular. Vive también las nuevas evidencias de su papel protagónico en el drama de comunicar; el "Markask'a" lo anuncia así: "-Me has hecho hablar- dijo. Todo lo que pienso a solas lo he cantado. No sé por qué, contigo se abre mi pensamiento, se desata mi lengua. Es que no eres de acá, los abanquinos no son de confiar..." (115).

Vemos hasta qué punto el emisor, testigo y actor del drama, se ha convertido en el destinatario: en el texto que inscribe un testimonio más vasto, una acción más amplia; y donde los hablantes rinden el discurso que los constituye.

La licencia de estas ampliaciones del decir sólo pueden ser penadas por el sistema, el Padre Director así lo declara: "-Es mi deber sagra- 
do. Has seguido a la indiada, confundida por el demonio. ¿Qué has hecho, qué han hecho? Cuéntale a Dios, junto a su altar" (116, cap. 7: "Quebrada honda"). El interrogatorio, la confesión, muestran al sistema institucional procesando la información desde su condena. "Si eres inocente no juzgues", advierte el Padre; y sentencia: "_Eres enfermo o estás enfermo. O te han insuflado algo de su inmundicia, iArrodillate!"(117). "El castigo y los rezos me habían empequeñecido", comprueba el narrador, su disyunción con el sistema se ha producido. No sin agonía: "La voz de los internos, la voz del Padre; la voz de Antero y de Salvinia, la canción de las mujeres, de las aves en la alameda de Condebamba, repercutían, se mezclaban en mi memoria; como una lluvia desigual caían sobre mi sueño. La luz del sol suele aparecer en medio de las lluvias dispares; fulge por algún vacío de las nubes, y el campo resalta, brilla el agua, los árboles y las yerbas se agitan, iluminados; empiezan a cantar los pájaros. El hombre contempla, indeciso, el mundo así disputado, sacudido por el sol y las nubes tenebrosas que se precipitan"(118).

Los modelos se han manifestado en su ambigüedad, en su polaridad; y también en sus aproximaciones y ampliaciones. Y en esta página decisiva se sobreimponen como un drama: el modelo de la comunicación en el mundo social es el de las voces disputadas, el modelo de la comunicación en el mundo natural es el de la luz que impone un orden armónico. Ambos modelos están ahora yuxtapuestos: debajo del social, como la posibilidad de su reordenamiento, está el del mundo natural. Tal vez el mundo es una disputa de ambos, pero la única alternativa de su sentido radica en que el modelo natural reformulc y sustente al modelo social. El desorden anti-natural de éste es un verdadero mundo al revés; y su imposición un escándalo de injusticia. Pero en la interacción de ambos órdenes se han generado márgenes, zonas dinamizadoras de una vía alterna que podría trabajar, por ejemplo, con su rebelión, una modificación de los términos de la dominación. Ese debate no podrá ser resuelto en el nivel del relato, pero sí será reformulado en el sentido final del texto mismo.

Si es evidente que en la práctica social peruana sólo podemos reclamar que las culturas nativas no sean vistas como un "problema indígena" por resolverse en un "mestizaje" nivelador y una "integración" a la "vida nacional" (nivelación e integración que sólo refuerzan los términos desiguales de la dominación que ejerce la sociedad nacional a través de su sector moderno); no es menos evidente que en sus novelas José María Arguedas ha postulado la legitimidad intrínseca de la cultura andina - que es ciertamente un proceso de información no-niveladademostrando, a la vez, la violencia ejercida sobre ella por la cultura occidentalizada, pero -y ésta es la más aguda indagación de su obra-, también explorando esas zonas mixtas donde las polaridades son resueltas sincréticamente y ya desde otra práctica social. Así, estas novelas no reemplazan a la antropología, sino que levantan un dramático texto literario-cultural que es al mismo tiempo denuncia y revelación, crítica y poesía. Un texto que reelabora la pluralidad de un sentido firmemente enraizado y socialmente zozobrante. El proyecto, así, de una cultura pluralista, donde varias naciones y minorías coexistan en paridad, no es simple 
utopia: es el dilema más actual de la cultura hispanoamericana, y la forma moderna de nuestra cultura política ${ }^{23}$. En los textos de Arguedas ese proyecto se adelanta con una alternativa andina: la existencia generadora de un modelo genuino, capaz de humanizar y enriquecer con su capacidad de comunicación al modelo supuestamente civilizador.

\section{TEXTo, Mito Y SUJETo}

\section{Ritual y mediación}

Luego del motín, la recomposición del sistema dominante buscará todavía una recodificación del espacio (cap. 8: "Quebrada honda"), desde el aparato religioso, primero, y desde el policial después. Esta práctica muestra sensiblemente la "territorialización" que el sistema impone. Recobrando la palabra pública, el Padre se dirige al pueblo para proclamar en el sufrimiento universal una conciliación supra-social del mismo orden injusto, y termina reclamando a su auditorio la expiación del llanto común (120). Una segunda rebelión se produce en Ernesto: rehusando arrodillarse, huye. Y por medio del nuevo instrumento mediador, el trompo layk'a (brujo) que Antero ha hecho para él, la comunicación subvierte sus propios órdenes: canta el trompo y "el zumbido fue haciéndose más intenso, penetraba en el oído como un llamado que brotara de la propia sangre del oyente" (124); ante lo cual " iNo habrá escarmiento!", celebra él, como si la voz del trompo mágico liberara también a la fugitiva doña Felipa. Este trompo adquiere otro tipo de mediación: es "mezcla de ángel con brujos" (125)y connota la vida afectiva de Antero y Ernesto. Por eso, se convierte en mensajero mágico: "Si lo hago bailar, y soplo su canto hacia la dirección de Chalhuanca, cillegaría hasta los oídos de mi padre?”(126). Antero responde planteando un verdadero esquema de la nueva comunicación: "Tú le hablas primero en uno de sus ojos, le das tu encargo, le orientas al camino, y después cuands está cantando soplas despacio hacia la dirección que quieres; y sigues dándole tu encargo. Y el zumbayllu canta al oído de quien te espera" (126). El ritual de este acto de comunicación mágica, proyectada por el objeto mediador, es característico de la cultura tradicional, sólo que aquí el mensaje es la reafirmación del sujeto: "Dile a mi padre que estoy resistiendo bien"; y un desafío al discurso antagónico: "QQue venga ahora el Padrecito Director!" (127).

Estas armas mágicas (como el rondín de Romero, a través de cuya música "el mundo se nos acercaba de nuevo" 134), son tácitamente confrontadas con las otras, las de la policía que sofoca los últimos rastros de la rebelión y persigue a doña Felipa. La violencia de la re-

${ }^{23}$ ENRIQUE MAYER, "Consideraciones sobre lo indígena", en Perú: identidad nacional, op. cit., pp. 79-108. STÉF ANO VARESE, Las minorias étnicas y la comunidad nacional, Lima, 1974, y Defender lo múltiple: nota al indigenismo, Oaxaca (México), 1978, mimeogr. 
presión trastorna el orden natural como una convulsión que no sólo se explica en términos humanos sino que compromete a fuerzas cósmicas:

Algún mal grande se había desencadenado para el internado y para Abancay; se cumplía quizá un presagio antiguo, o habrían rozado sobre el pequeño espacio de la hacienda Patibamba que la ciudad ocupaba, los últimos mantos de luz débil y pestilente del cometa que apareció en el cielo, hacía sólo veinte años. "Era azul la luz y se arrastraba muy cerca del suelo, como la neblina de las madrugadas, así transparente", contaban los viejos. Quizá el daño de esa luz empezaba recién a hacerse patente. "Abancay, dice, ha caído en maldición", había gritado el portero, estrujándose las manos. "A cualquiera ya pueden matarlo. .." (136)

Lo importante aquí es que el "fenómeno natural" (extraordinario, para la cultura tradicional) sea empleado para buscar una explicación a la violencia. Y ello es así porque el hablante colectivo ("contaban los viejos") sólo puede apelar a su cultura para explicarse el sesgo insólito del acontecimiento, no otra cosa había hecho Guamán Poma de Ayala cuando se explicó la conquista como un cataclismo ${ }^{24}$. La ruptura del orden natural denuncia la violencia represiva: es por ella que esa fisura se produce.

"Desconcertados y anhelantes"(136), los estudiantes reaccionaron con una exaltación imprecisa, sin poder controlar una información que los desubica. El Hermano negro es eje de otro ejemplo: su dominio del habla no está en contradicción con su color (139), pero esta marca no lo sitúa, sin embargo, junto a los otros signados por distintos grados del mestizaje, ya que este Hermano forma parte de la ideología dominante. También el orden dominante puede decidir sobre el otro con su propia magia: entre el objeto "brujo" (el trompo híbrido) y la bendición católica (que imparte el Hermano) se produce una lucha de la información en dos distintos modelos. "YYa no es brujo, entonces! iYa está bendito!"'(140) sentencia Palacitos, el muchacho campesino, expresando esa disputa. O sea, la colonización que el modelo impone, a través de sus aparatos, extravía la naturaleza cultural de los objetos mágicos. No obstante, la lucha no cesa: la manifestación de sus términos es una de sus formas. Ante la duda de si el trompo es o no es brujo luego de la bendición, Romero protesta: “ iAlgo ha de tener!"'(140). Y el narrador resume: "En su alma hay de todo. Una linda niña, la más linda que existe; la fuerza del 'Candela'; mi recuerdo, lo que cra layk'a; la bendición de la Virgen de la costa. iY es winku! Lo harás bailar a solas"(140-141). Este pasaje es un programa sintético de esa cultura plural que el texto elabora: el objeto "mestizo", un objeto introducido en la cultura andina desde fuera, y colonizado por ella,

24 JUAN OSSIO, op. cit., supra. Rolena Adorno, "Paradigms lost: A Peruvian indian surveys Spanish colonial society", Studies in the Anthropology of Visual Communication, Spring, 5 (1979), pp. 78-96. 
es, en verdad, un instrumento proliferante (winku: marcado por su forma protuberante, no del todo redonda); esto es, un signo heterodoxo, capaz de significar una y otra cultura, incorporar datos de una y otra fuente, $y$, confrontando incluso la fuerza de la otra cultura, capaz de reafirmarse en su marca diferencial.

Así, este signo abre un proceso de comunicación definido 1) por su forma occidental modificada por la materia andina y su variación descentrada, 2) por su función andina ritual, y 3) por su incorporación de datos de la cultura hispánica. Este carácter plural refuerza la práctica cultural de la sociedad andina, al reafirmar su perspectiva como eje de participación e incorporación. En el texto, además, este principio plural propone la alternativa de una productividad que separa, discierne y religa, desde los operadores textuales, construyendo así el lugar del tex to (pluridimensional) en la posibilidad del sujeto (múltiple).

La discusión sobre los objetos mediadores es asimismo un informe sobre el ritual comunicativo:

- Abancay tiene el peso del cielo. Sólo tu rondín y el zumbayllu pueden llegar a las cumbres. Quiero mandar un mensaje a mi padre. . .

-El agua también sirve -me dijo Romero. Ahí está la del Colegio; viene desde un manantial. . Háblale poniendo la boca sobre el chorro.

-No creo, Romerito. No puedo creer. La cordillera es peor que el acero. Si gritas, rebota la voz.

-Pero el agua filtra hasta en la piedra alaymosca. ¿No has visto que de los precipicios de roca gotea agua?

- ¿Por dónde va a entrar el agua a la casa en que mi padre, a esta hora, quizá se pasea?

- ¡Buen cholo forastero eres! ¿Tu sangre acaso no es agua? Por ahí le habla al alma, el agua, que siempre existe bajo la tierra. (147, cap. 9: "Cal y canto")

Esta revisión del canal de la comunicación muestra distintos grados de certeza dentro de una cultura intermediaria que los asume sin conflicto. Romero y Palacios informan que la lata en el rondín impediría la transmisión del mensaje: le quitan, por eso, la lámina desnudando la madera. Este episodio refuerza las convicciones del narrador con nueva información y en un "nosotros" culturalmente ligado y plural. "Si la voz del winku no te ha llegado, aquí va un carnaval", dije, pensando en mi padre, mientras Romero tocaba su rondín. "iQue quiera vencerme el mundo entero! iQue quiera vencerme! iNo podrá!"(148). El mensaje del acto comunicativo es la comunicación misma, esto es, el reconocimiento de las fuentes que dan forma cultural al sujeto.

Pero aun la identidad cultural reconoce la estratificación social en su interior: Antero y Ernesto comparten el código cultural, pero su posición de clase no es la misma; lo que se evidencia en sus distintas actitudes ante el motín. Los colonos (los indios de hacienda) de Ábancay están sometidos brutalmente: "Aquí parece que no los de- 
jan llegar a ser hombres" (155), observa Ernesto, quien no ha visto una sumisión semejante. "-Yo, hermano, si los indios se levantaran, los iría matando, fácil"'(156), confiesa Antero, lo que espanta a Ernesto, porque su amigo sí ha sido capaz de conmoverse con la situación de tales colonos. "Tú no puedes entender, porque no eres dueño" (156), explica Antero.

Doña Felipa, en cambio, es la figura contrapuesta al Padre Director: su marginalidad, su fuga, le confieren una dimensión heroica. Al mismo tiempo, su condición de líder impugnador sólo parece posible en esa marginalidad. Hacia ella se desplaza la orientación del mensaje: "En el canto del zumbayllu le enviaré un mensaje a doña Felipa. iLa llamaré! Que venga incendiando los cañaverales, de quebrada en quebrada, de banda a banda del río. iEl Pachachaca la ayudará!" (157). Los signos del río ("el ruido de sus aguas se extiende como otro universo en el universo" (152), y del canto de la calandria ("la materia de que estoy hecho" 158), son otros instrumentos de la comunicación natural que recusan (poderosamente, a pesar de su entidad vulnerable) a los instrumentos del represor.

\section{La transgresión mítica}

La persecusión de doña Felipa ha transtornado al pueblo, ocupado ahora por las tropas. Pero es más profundo el desorden que se deriva de la violencia: "A los muertos de la guerra ni la madre luna los compadece. No llora por ellos, dicen. Ni en los dientes del cadáver su luz alumbra. . . En los campos donde ha habido guerra los huesos han de padecer hasta el día del juicio" (175, cap. 10: "Yawar mayu"). El temor por la suerte de la mujer rebelde no hará sino agudizar el contraste entre la violencia y los signos del sentido, ahora dramatizados por la alarma: “el ritmo era aún más lento, más triste; mucho más tristes el tono y las palabras. La voz aguda caía en mi corazón, ya de sí anhelante, como un río helado". Y, enseguida: “¿Por qué en los ríos profundos, en estos abismos de rocas, de arbustos y sol, el tono de las canciones era dulce, siendo bravo el torrente poderoso de las aguas, teniendo los precipicios ese semblante aterrador?" (181). Con los signos del lenguaje del mundo, el texto interroga la discordia del discurso social.

Otra confrontación se ha producido entre el habla limeña de los hijos de los jefes militares llegados con la tropa, y el reconocimiento del narrador y un arpista indio. Si este reconocimiento remite al origen, la presencia de los nuevos muchachos remite al destino social conflictivo. El narrador resiste la presencia de los militares, a quienes percibe como algo "no natural" (202, cap. 11: "Los Colonos"), como "disfrazados"(203). Esta introducción del orden nacional en el pueblo revela, por lo demás, su pertenencia a ese orden, lo cual des- 
concierta a Ernesto, que rechaza los ritos sociales dinamizados por la presencia de los forasteros. Incluso Romero ha cedido a esa dependencia del pueblo a un sistema devaluador:

-No hay discusión -decía. En la costa saben más que nosotros; tienen más adelanto en todo.

Dejó de tocar su rondín varias noches. . .

-Casi te avergüenzas del huayno, ¿no? --le pregunté.

- ¿Será eso? -dijo (211).

Pero no se trata de un dualismo simple, sino de una más activa confrontación del sujeto que, ante la invasión depresora, se identifica por primera vez con la comunidad de Abancay, a la que ve en peligro de ser trastocada por un orden antinatural. Ante esta zozobra mayor, Ernesto decide enterrar su trompo (212) que después rescatará, porqué "Ahora habrá aprendido quizá otros tonos, ya que ha dormido bajo la tierra"(218).

Si el motín de las chicheras fue una subversión del orden social, la presencia de la peste será una subversión del orden natural. En la primera, reclamando la sal, las mujeres han denunciado el carácter injusto del dominio estatal y su orden represivo. En la segunda, los colonos invadirán el pueblo reclamando del orden religioso una ayuda divina que ellos, desde su cultura, creen matará a la peste. En ambos casos, la participación del narrador será activa: viviendo la rebelión colectiva primero, viviendo la muerte colectiva después.

El texto ha producido estas dos metáforas decisivas del conflicto de la comunicación en los dos órdenes; $y$, al hacerlo, deduce una relación inquietante entre una y otra. En primer término, las autoridades rechazan la posibilidad de la peste, incluso en el colegio, como si pusiese en cuestión esa misma autoridad. Romero deja ver el sesgo de ese rechazo: "- iCuentos! . . . Desde la llegada del regimiento inventan en los barrios esos cuentos. iQue la peste ha de venir, que los chunchos, que el 'yana batalla'!'(214-215). Esta duda sobre la información cuestiona sobre todo al emisor colectivo: al pueblo de esos barrios. Ahora bien, ¿por qué Romero vincula la llegada del regimiento represor y las noticias o rumores apocalípticos? Es evidente, pues, que para el emisor popular el desorden del mundo social (la imposición de la violencia) se traduce en el caos del mundo natural (la peste que amenaza a todos); deducción que pertenece a la lógica de la percepción tradicional, y sobre ella el texto generará su propia estructuración. Romero vuelve a rechazar las evidencias para rehusar esa lógica: "No hay peste en ningún sitio. Las chicheras se defienden o se vengan, ¡Ojalá las zurren de nuevo!" (217). Y cuando muere la demente, una mujer reza en quechua: “Ha sufrido, ha sufrido! Caminando o sentada, haciendo o no haciendo, ha sufrido. iAhora le pondrás luz en su mente, le harás ángel y la harás cantar en tu gloria, Gran Señor. . .!"(219). Es un mundo al revés lo que concluye con su muerte; 
un mundo donde vivió condenada a la falta del habla: en el otro mundo, un orden se habrá restituido, y ella hablará.

El narrador participa del desgarramiento definitivo que se cierne: su misma vida está en peligro, y la exaltación de su papel de mensajero, de intermediario entre uno y otro orden, busca dar forma al sentido de esta muerte ritualizada por la cultura aborigen. Una imagen india de la muerte se levanta: "Les gusta hablar mucho de la muerte, a indios y mestizos; también a nosotros. Pero oyendo hablar en quechua de ella, se abraza casi, como a un fantoche de algodón, a la muerte, o como a una sombra helada que a uno lo oprimiera por el pecho, rozando el corazón, sobresaltándolo; a pesar de que llega como una hoja de lirio suavísima, o de nieve, de la nieve de las cumbres, donde la vida ya no existe"(226).

La lengua quechua, otra vez, dice más: ahora, conjura el terror de la muerte, encontrando sus símiles naturales. Si el "nosotros" que se enuncia en este pasaje no corresponde a indios ni a mestizos, ca quién supone? Observemos que quien se responsabiliza por ese enunciado es el "narrador-testigo", aquél que se aproxima más a la superficie de la lectura. Parece, por ello, verosímil que ese nosotros incluya al "autor" y a los lectores de la cultura occidentalizada porque enseguida distingue (como un informante) que otra cosa es hablar de ella en quechua (que presupone no conocemos). Por una vez el Narrador se ha separado de su "actor" (mestizo, híbrido, plural), y ha supuesto una lectura desde "el otro lado" de la página, al que hay también que incorporar al drama. La imagen de la muerte se completa cuando el "actor" imagina la suya propia: "Bajaría por la cuesta de tierra roja, de Huayrala; con esa arcilla noble modelaría la figura de un perro, para que me ayudara a pasar el río que separa ésta de la otra vida. Entraría tiritando a mi pueblo; sin un piojo, con el pelo rapado. Y moriría en cualquier casa que no fuera aquélla en que me criaron odiándome porque era hijo ajeno. Todo el pueblo cantaría tras el pequeño féretro en que me llevarían al cementerio. Los pájaros se acercarían a los muros y a los arbustos, a cantar por un inocente" (228). Que es, ciertamente, una muerte india, con su ritual y su reintegración al canto del mundo.

Más intrigante es la marcha de los colonos hacia el pueblo, que el narrador (223 s.) prevé y un fugitivo anuncia (236). En esa marcha hay, en primer lugar, una fuerza subversiva: los guardias intentan impedir que crucen el río pues se les considera ya apestados, pero ellos vencen la resistencia. Una explicación asegura que "El colono es como gallina; peor. Muere no más, tranquilo. Pero es maldición la peste. ¿Quién manda la peste? iEs maldición! iInglesia, inglesia, misa, Padrecito!' están gritando..." (236). Finalmente ingresan al pueblo ("Los colonos subían, verdaderamente como una mancha de carneros, de miles de carneros" (239), y el Padre dirá una misa para ellos. Ernesto lo interroga: 
- ¿Dirá usted un sermón para los indios?

- Los consolaré. Llorarán hasta desahogarse. Avivaré su fe en Dios. Les pediré que a la vuelta crucen la ciudad rezando.

-Irán en triunfo, Padre, así como vienen ahora, subiendo la montaก̃a (241).

Episodio ambiguo, donde el sistema dominante parece reforzarse: tanto por la necesidad de comunicarse en su aparato religioso que revelan los colonos, como por la autoridad reconstruida del Director, triunfal en su papel. Y, sin embargo, desde la cultura indígena funciona una percepción distinta, que se explica y responde a su modo a la amenaza de la peste; esto es, como a una "maldición", como a un desorden cósmico que deben conjurar. La misa es parte del ritual que saben deberán poner en práctica: su desafío a la muerte para llegar a la iglesia y pedir la misa, anuncia la importancia decisiva que ellos otorgan a su papel de participantes de una ceremonia conjuratoria. Su lucha contra la peste forma parte de una práctica mítica para restablecer un equilibrio vital fracturado. Por eso, luego de la misa, recorren las calles gritando "fuera peste". Y, "lejos ya de la plaza, desde las calles, apostrofaban a la peste, la amenazaban" (242). A esto parece haberse referido Ernesto al anunciar que volverán los colonos "en triunfo". Mientras marcha de regreso al Cuzco, enviado por el Padre a casa del Viejo, Ernesto prevé la culminación de ese triunfo: "Llegarían a Huanupata, y juntos allí, cantarían o lanzarían un grito final de harahui, dirigido a los mundos y materias desconocidos que precipitan la reproducción de los piojos, el movimiento menudo y tan lento de la muerte. Quizá el grito alcanzaría a la madre de la fiebre y la penetraría, haciéndola estallar, convirtiéndola en polvo inofensivo que se esfumara tras los árboles. Quizá" (242 s.).

Al final, el narrador no sólo ha participado de los hechos del mundo fracturado por el caos de la enfermedad; sino que ha hecho suya la percepción mítica aborigen, la que incorporando el ritual católico al suyo propio responde por el equilibrio del mundo desde su zozobrante conjuro contra la muerte. Respuesta más dramática por venir de un grupo ferozmente desposeído. Al incorporarse al mito, el mismo texto disuelve la amenaza de la peste: "estaría... aterida por la oración de los indios, por los cantos y la onda final de los harahuis"; y el narrador así lo confirma: "Si los colonos, con sus imprecaciones y sus cantos, habían aniquilado a la fiebre, quizá, desde lo alto del puente la vería pasar arrastrada por la corriente, a la sombra de los árboles. Iría prendida de una rama... El río la llevaría a la Gran Selva, país de los muertos" (244). La forma condicional sólo matiza el acto final de la escritura: la expulsión de la muerte, su destierro; acto de restitución de la fuente mitica que informa y nutre el final abierto del texto. Final del relato y recomienzo del sujeto, el texto concluye como una culminación cíclica: abriendo otro inicio.

El mito es, por tanto, el principio ordenador del significado del 
mundo, y el conocimiento aparece como la articulación de una conciencia mítica, o sea, de una forma que confirma aquel significado. En el debate del relato, esa conciencia se elabora proyectando su práctica analógica, buscando informar la discordia entrópica del mundo antinatural, incorporando y separando elementos, reforzando, en fin, su percepción para retornar al ciclo mítico re-estructurado.

En el inmanentismo panteísta de esa percepción, que supone la revelación de la experiencia en la comunión con el mundo natural, podemos ver que la existencia social aparece como una naturaleza caída, desligada, una transferencia se ha producido, con su énfasis de culpa cósmica, del orden religioso católico al orden panteísta andino. Este complejo sistema panteísta, que es también un conjunto ideoafectivo, está hecho, por cierto, de una conjugación de elementos a veces dispares, y requeriría un estudio aparte. Uno es, aparentemente, el panteísmo de la cultura popular; otro el que se muestra en el protagonista y su percepción puesta en conflicto, que debe reordenar información dispar. $Y$, además, el texto mismo responde a esta unidad panteísta del principio creador y lo creado, al producir un movimiento textual paralelo; en efecto, como hemos visto, el texto es una suma de narradores que postulan un sujeto; en esa suma hay otra: la biografía personal y cultural del mismo autor, cuya mayor o menor fidelidad a la fábula no viene al caso, pero cuya articulación textual es fundamental para una novela que demanda a la "ficción" ser una forma sustantiva de la "verdad". Dicho de otro modo, el radicalismo del texto pone en tensión al género, al discurso que conocemos como "literario". Biografía y cultura son, pues, escritura extremada por su re-escribir cultural. No en vano el texto se formula como una verdadera "invención" del sujeto. La posibilidad del sujeto se entrega a esa aventura peligrosa que es la suerte del texto en su cotejo de los modelos y los códigos. La unidad articulatoria y disyuntiva que el texto pone en práctica lo transforma en un programa condensado de la cultura plural. Pero, sobre todo, en un instrumento cuyo principio ordenador es convertir a su propio sistema la percepción literaria y cultural del lector. Esa práctica supone la participación del lenguaje mismo en un discurso transliterario, re-codificado por el texto. Si el mito es el principio ordenador en la cultura tradicional, el texto lo es en esta lectura de las transformaciones de la cultura re-escrita. Ya esto mismo presupone el rebasamiento del género, excedido por las articulaciones del texto mito-poético.

No carece de interés comprobar que las correlaciones establecidas para el mito por Lévi-Strauss podrían ser seguidas en esta novela. Las propiedades formales del mito, efectivamente, están en el texto reproduciendo la crisis del sistema de parentesco (el hijo ajeno, que es un hijo errante, los sucesivos padres autoritarios frente al padre real, desterrado, y los padres y madres equivalentes, en la comunidad); sistema que aparece como otro conflicto de la pérdida del sentido; y es- 
tán, en fin, reproduciendo asimismo las estructuras lingüísticas y formales del texto. O sea, son correlaciones paralelas, ya que aquí el mito tradicional, ese relato que dramatiza las relaciones de naturaleza y cultura, aparece dentro de una fábula más amplia y compleja. Lo interesante está, entonces, en el hecho de que la forma misma del texto tome del mito su elaboración del significado.

Desde la perspectiva del modelo actancial (Propp, Lévi-Strauss, Greimas) podríamos proponer el esquema del discurso en la novela: Sujeto -Hijo; Objeto - Comunicación; Emisor - Cultura andina; Destinatario - Cultura hispánica; Adyuvante - Mundo natural; OponentePoder. En otro sentido, el "sujeto" actancial es el "sujeto" simbólico, y lo es a través de sus actuaciones como hijo, aprendiz, rebelde, agonista y, en fin, artista. Que el "objeto" de la estructuración semántica de la comunicación sea la "comunicación" misma, indica bien el carácter autorreferencial de la aventura de este discurso, proceso y búsqueda, el objeto se sustenta a sí mismo, pone a prueba su eficacia, controla los estados entrópicos y genera, en su drama, la significación del sujeto. El emisor es aquí un universo semántico formalizado por el texto y, lo mismo, el destinatario: sus relaciones con una efectiva etnología de ambos órdenes supondría otra discusión; son sus relaciones en la comunicación producida por el texto lo que aquí se reformula. El conflicto del adyuvante y el oponente es más explícito, y marca la mayor subversión del sentido que el texto promueve.

El análisis semántico de A. Greimas ${ }^{25}$ nos permite ampliar estas observaciones. Las relaciones remitente/destinatario (eje de la comunicación, modalidad del saber), muestran que la capacidad del sujeto para discernir su función se define en el conflicto cultural que requiere recorrer antes de percibir la alternativa de un sistema activo dentro de otro. Las relaciones sujeto/objeto (eje del desear, modalidad del poder), muestran que la búsqueda de la comunicación demanda al sujeto la exacerbación del deseo, su proyección, y en ello el redescubrimiento de su propia percepción. Las relaciones adyuvante/oponente (eje de la participación, modalidad de demandar), muestran, por último, que el reconocimiento de la identidad plural se da en la actividad de inclusión del sujeto, y en su puesta a prueba de ambos modelos; con lo cual su participar es una denuncia y una opción frente al poder desde una razón "natural", mítica, crítica.

La ampliación que propuso Lotman del modelo de la comunicación de Jakobson nos permite otro acceso al complejo comunicativo en nuestro texto. En efecto, según el modelo de Jakobson la dirección más característica de la comunicación es del Yo al Él: una fuente remite un mensaje a un receptor. Según Lotman, este tipo de di-

${ }^{25}$ A. J. Greimas, Sémantique structurale, Paris, 1966; Jean-Claude CoQuet, Sémiotique littéraire. Contribution a l'analyse sémantique du discours, Paris, 1973; JULIA KRISTEva, Polyloque, Paris, 1977. 
rección domina en nuestra cultura (supone pocos emisores y muchos destinatarios), pero oculta otro tipo: la comunicación del Yo al Yo, en la que el remitente y el destinatario son el mismo. Este segundo modelo de auto-comunicación es más evidente en la "sociedad tradicional", y presupone una mayor actividad espiritual que el primero. Las sociedades cuentan con ambos modelos, aunque es claro que el primero predomina: la historia demuestra que las culturas más viables son aquellas donde ambos sistemas compiten sin lograr imponerse uno sobre otro, concluye Lotman. Es notoria la vecindad de la percepción cultural de Arguedas a esta reflexión.

Lotman observa, además, cómo en el modelo auto-comunicativo, que incluye al "nosotros" de la cultura "tradicional", el nivel de contenido puede transformarse en un nivel de expresión. Y esto es precisamente lo que ocurre con el tratamiento mítico en Los rios profundos. Lo cual no indica que el mensaje sea desprovisto de su densidad semántica, sino que el relato lo desplaza de contexto (desde la cultura andina lo moviliza, exteriorizándolo, a la estructuración tex tual); y en ese movimiento, la noción cultural del mito se ha transfigurado en el objeto textual de una serie configuradora. Esto es, en un sintagma que el texto produce en su práctica constructiva del sujeto y desconstructora del mundo previsto para ese sujeto ${ }^{26}$.

La poderosa denuncia social del texto no hace sino acentuarse en su organización mítica. Porque las oposiciones binarias que el mito incorpora de la sociedad se funden en él, pero a la vez esas oposiciones se muestran en la explicación que pone en práctica la cultura tradicional para resolver los conflictos. Incidencia del mito, y al mismo tiempo derivación mítica del propio texto en su opción final: entregándose al mito, el texto anuncia que su saber último se da en tanto forma del sentido culturalmente restituido.

No es un sujeto escindido el que se deduce del texto, sino un sujeto dramatizado por la información que procesa, y por su búsqueda de una comunicación sustentadora. Es probable que la sociedad peruana no reconozca la legitimidad de este sujeto plural que se propone incorporarla a un debate sobre su error profundo y plantearle una alternativa genuina. Es incluso posible que la sociedad nacional lo condene como sujeto escindido y sin lugar. Pero el acto de la novela, y el del sujeto en ella, es un acto plural y alternativo dentro de un orden social cuya manipulación comunicativa es un acto enfermo. Por eso, lo que al comienzo llamamos el drama del sujeto en la escritura es su radical cuestionamiento del programa social y su contrato. Si el programa se denuncia en su ambivalencia, el contrato es recusado por la ruptura misma que supone un diseño alternativo. De la crítica del programa se suscita la rebelión, de la ruptura del contrato se genera

26 JURIJ LOTMAN, "Two models of communication in the system of culture", Trudy, 4, pp. 227-243, y "Culture and information", Dispositio, 1976, núm. 1, pp. 213-215, además del trabajo colectivo con B. A. Uspensky ya citado. 
otro espacio, el que escrito por el río y el canto en el mundo natural es re-escrito por el texto en la reconstrucción de otro lenguaje: espacio de la otredad donde la subversión del sujeto inscribe una comunicación fecunda, una comunidad posible.

JULIO ORTEGA

The University of Texas, Austin. 